\title{
KERKLIKE KONTAK TUSSEN DIE AFRIKAANSE EN ENGELSE KERKEGROEPE IN SUID-AFRIKA
}

ONS bied allereers 'n ekskurs, waarin aandag gegee word aan die ekklesiologie by J. Calvyn, W. J. Snyman en B. Duvenage. Tweedens maak ons 'n diagnose van die kerklike kontak tussen die Afrikaanse en Engelse kerkegroepe, en ten slotte waag ons 'n ekklesiologiese prognose.

\section{Ekskurs}

\subsection{Die ekklesiologie van J. Calvyn}

Vir 'n sinvolle weergawe van Calvyn se ekklesiologie, waarby die eenheid van die Kerk 'n onderafdeling vorm, is eerstens sy hoofwerk, die Institusie, ${ }^{1}$ onontbeerlik, maar eweneens die uiters belangrike boek van W. Nijenhuis, Calvinus Oecumenicus, ${ }^{2}$ waarin hy op gedetailleerde wyse Calvyn se eenheidstrewe vanuit sy briewe belig. Hierdie lg. boek het tewens 'n geweldige bydrae gelewer tot die belangstelling in en bewoënheid oor kerklike eenheid wat daar die afgelope paar jare in die Geref. Kerk in S.A. te bespeur is.

Die Heilige Skrif spreek volgens Calvyn in tweërlei sin van die kerk: van die onsigbare kerk, dit is die uitverkorenes, wat alleen deur Gód geken word en van die sigbare kerk, dit is ,de ganse menigte der mensen, die over de aarde verspreid is", waaronder ook die huigelaars. ${ }^{3}$ Hy wys daarop dat die kerk "katoliek" of ,algemeen" genoem word, ,omdat men geen twee of drie kerken kan vinden, zonder dat Christus verscheurd wordt: wat onmogelijk is". ${ }^{4} \mathrm{Hy}$ ag die afvalliges „die er op uit zijn om de ((sigbare!)) kerken te scheuren" verfoeilik. Calvyn maak egter nog 'n verdere onderskeiding nl. tussen die ,algemene kerk”, dit is die ,uit allerlei volkeren verzamelde menigte”, en die „afsonderlike kerke” in stede en dorpe. ${ }^{\theta}$ Die kenmerk van die ware sigbare kerk is die suiwere prediking én aanhoor van die Woord van God en die Christologiese bediening van die sakramente. ${ }^{7}$ Waar dít voorkom, mag die eenheid nie verbreek word nie. ${ }^{8}$ Ons moet op ons hoede wees vir 'n ,misdadige scheiding". "Uit de kerk weggaan betekent verloochening van God en Christus". Waar Woord en sakramente suiwer funksioneer, dáár is die ware kerk. Die betekenis hiervan is só verreikend „dat die kerk nooit verworpen mag worden, zolang ze daarbij blijft, ook al is ze overigens vol van fouten. Ja zelfs zal er in de bediening van de leer of der sacramenten enige fouten kunnen insluipen, zonder dat die ons van haar gemeenschap behoort te vervreemden".10 En dan maak Calvyn in hierdie verband ' $n$ onderskeiding wat in die latere teologie - selfs tot vandag toe - 'n besonder groot rol sou speel in die eenheidsen konfessionele problematiek, nl. dié tussen ontwyfelbare "hoofdstukken der ware leer" en ander "niet zo noodzakelijke zaken". Onder de „hoofdsom der religie” reken hy dan „dat er één God is, 
dat Christus God is en de Zoon Gods, dat onze zaligheid gelegen is in Gods barmhartigheid en dergelijke”. Hy voeg hieraan toe: „Er zijn andere, waarover tussen de kerken geschil is, maar die toch de eenheid des geloofs niet verscheuren". ${ }^{11}$ Hy noem pertinent dat hy nie hiermee selfs maar die allergeringste dwalinge wil beskerm nie, maar hy plaas sy visie in eenheidskonteks: ,ik bedoel, dat we nooit lichtvaardig, om het een of ander klein verschil, de kerk moeten verlaten". ${ }^{12} \mathrm{Hy}$ wil selfs met sy toegeeflikheid ,veel verder gaan" en wys die sektariërs daarop dat 'n mens tevergeefs 'n kerk soek ,die met geen enkele vlek bespat is".13

Ter motivering van hierdie waarheid dat die kerk nie sommerso verlaat mag word nie, verwys Calvyn na die N.T. en O.T. Hy verwys na die gemeente van Korinthe, waar geen ,lichte dwalingen" maar "gruwelijke schandalen" in sedes en leer (die loëning van die opstanding!) voorgekom het. Wat was Paulus se reaksie hierop? „Zoekt hij een scheiding van hen?" Nee, ,hij erkent en predikt, dat zij is een kerk van Christus en een gemeenschap der heiligen". ${ }^{14} \mathrm{Hy}$ verwys ook na die Galasiërs, "die bijna het evangelie verlaten hadden", maar waar Paulus tog ",kerken" gevind het.15 Calvyn wys in hierdie verband elke individualistiese optrede af: „ook al zou de kerk in haar plicht nalatig zijn, dan mag daarom nog niet terstond ieder lid oordelen, dat hij zich moet afscheiden". Dit gaan nie soseer om kérkondersoek nie as om sélfondersoek ( 1 Kor. $11: 28){ }^{16} \mathrm{Hy}$ wys daarop dat die heiligheidsdrywers moet onthou dat ons nie in ons ons ywer vir 'n volkome volmaakte kerk, ,geen enkele kerk overlaten". ${ }^{17}$

Sy tweede verwysing is na die O.T. Daar was diep donker momente. „De godsdienst was deels veracht, deels besmet; wat de zeden betreft: overal wordt verhaald van diefstallen, roverijen, trouweloosheden, moorden en dergelijke misdaden. En toch richtten de profeten deswege geen nieuwe kerken op..." Ook by die profete het die eenheidsmotief gedomineer: „Niets anders hield hen er dus van af een scheiding te maken dan de begeerte om de eenheid te bewaren. Indien de profeten een gewetensbezwaar hadden om zich wegens de zeer vele en grote misdaden niet van één of twee mensen, maar van bijna het gehele volk, van de kerk te vervreemden, dan matigen wij ons al te veel aan, wanneer wij ons terstond aan de gemeenschap der kerk durven onttrekken, wanneer niet aller zeden ooreenkomen met ons oordeel of ook met de Christelijke belijdenis". ${ }^{18}$

Ná hierdie twee verwysinge - in die N.T. en O.T. - van 'n haas volkome geruineerde kerk, 'n kerk wat in leer en lewe soveel dwaashede en ketterye in hom omgedra het, is ons aandag skerp gespanne om te sien watter argumente Calvyn gaan aanvoer ter motivering van die breuk met Rome, te meer aangesien hy Rome met Israel gaan vergelyk.19 En of die „hoofdsom der religie” by Rome volkome ontbreek het...

Wanneer die valse met die ware kerk vergelyk word, onderstreep hy dat dit by die ware kerk gaan om die ,hoofdinhoud van de leer van de godsdienst", die „hoofdsom der religie" - waarsonder die kerk noodsaaklik ineenstort -, en nie soseer om ,geringe dwalin- 
gen" nie. ${ }^{20}$ Hy verwerp die verwyt van ,skeurmaker" te wees, omdat die openbare samekomste (van Rome) ",scholen van afgoderij en goddeloosheid" is. ${ }^{21}$ Die groot fout met Rome is dat daar die kenmerk van die ware kerk, nl. die Woord, ontbreek. ${ }^{22}$ Hy vergelyk Rome dan met Israel en konkludeer dat by Rome ,de hoofdsenuw, ja de ziel der kerk", nl. die Woord, vertrap word. ${ }^{23}$ Maar Calvyn het dan reeds soveel verval in die Ou-Testamentiese kerk gekonstateer terwyl dit nog kérk was, en 'n kerkskeuring onnodig, waarom kan dieselfde dan nie ook ten opsigte van Rome gesê word nie? Op hierdie kardinale vraag is daar net éen wesenlike antwoord moontlik: By Rome was daar ,een veel groter afgoderij" te vind as bv. in Israel onder Jerobeam. ${ }^{24}$ In 'n Roomse erediens vind daar "openlijke afgoderij" plaas - en dan verwys Calvyn na die mis. ${ }^{25}$ Daarom is ons situasie anders as dié van die profete: hưlle kon, selfs tydens 'n ,godsdienstoefening der goddelozen", hulle hou aan Gods verordeninge; maar ons word (deur die kerk) gedwing om daartéen te handel. Bowendien, watter profeet of vroom man het ooit in Bet-el aanbid?23

Moet Rome daarom afgeskrywe word? Nee, Calvyn meen dat by die pousgesindtes nog "spore" van die kerk te vind is - die doop behou tog ook sy krag! Die kerk van Christus is nie tot die fondament omvergewerp nie, maar wel „halfingestort” en „bouvallig”. ${ }^{27}$ Alhoewel hy konkludeer dat ,,iedere vergadering en ook het gehele lichaam van het pausdom de wettige gedaante van een kerk mist", ${ }^{28}$ noem hy tog - en dit verleen aan Calvyn se kritiek op Rome 'n sekere dialektiek - dat, ,hoewel we dus de titel kerk niet eenvoudigweg aan de pausgezinden willen toestaan, loochenen wij daarom niet, dat er bij hen kerken zijn”. Dáár is nog kerke „in zoverre de Here de overblijfselen van zijn volk, hoe ellendig verstrooid en uiteengejaagd dan ook, daar op wonderlijke wijze bewaart, in zoverre er enige kentekens der kerk blijven staan".29

Hierdie gegewens uit die Institusie kom wonderlik ooreen met Calvyn se korrespondensie. Nijenhuis het op indringende wyse 'n studie gemaak van Calvyn se eenheids-engagement, terwyl hy daarop gewys het dat Calvyn ook die eenheid van die sigbare kerk geaksentueer het. ${ }^{30}$ „Volgens Calvijns bezef konden de verschilpunten tussen de reformatorische kerken haar wezenlijke eenheid niet aantasten". ${ }^{31}$ Sy voortdurende gesprekke en korrespondensie met Lutherse, Zwingliaanse en Anglikaanse kerkegroeperinge spreek hier vanself. Dit is bekend dat Calvyn geen beswaar daarteen gehad het om sy handtekening te plaas onder die bekende Lutherse konfessie, die Confessio Augustana nie. ${ }^{32}$ „Die gedagte as sou die ware kerk van Christus met die Gereformeerde kerke sou saamval, terwyl die ander, soos bv. die Lutherane of die Anglikane, valse kerke of sektes was, was ten ene male vreemd aan Calvyn".33

\section{Calvyn se kontak met die Kerk van Engeland}

Ten opsigte van die konfessie voer hy die pleit vir 'n nuwe, eie, suiwere konfessie in Engeland met die oog op die suiwere prediking: „Men ziet, dat voor Calvijn de confessie niet dient om de ene 
kerk tegenover de andere af te grenzen, doch om de eenheid der kerk juist zichtbaar te maken en om de kerk af te grenzen tegenover de dwalingen van Rome en spiritualisten". ${ }^{34}$

In verband met die kerkregering is dit opvallend dat Calvyn nie die episkopaat aanval nie, maar die biskop adviseer oor die betere funksionering daarvan, veral ten opsigte van die handhawing van die kerklike tug. ${ }^{35}$ Uit Calvyn se beroemde brief aan aartsbiskop Thomas Cranmer blyk opnuut ,dat Calvijn tegen het episcopaat als zodanig geen principiële bedenkingen koestert". ${ }^{36}$ In bg. brief skryf Calvyn o.a. dat hy bereid is om tien seë oor te steek vir die eenheid van die kerk, nl. vir die hou van 'n reformatoriese konsilie soos deur Cranmer beoog. En verder:

„Tot de ergste misstanden van onze tijd moet ook gereken worden het feit, dat de kerken zozeer vaneengescheurd zijn, dat nauwelijks nog een menselijke gemeenschap onder ons bestaat, laat staan dat de heilige gemeenschap van de leden van Christus aan de dag zou treden, die wel door allen met de mond wordt beleden doch door weinigen met de daad ernstig beoefend". ${ }^{37}$ Calvyn was van mening "dat men zich door verschillen in liturgie en kerkorde niet mocht laten scheiden van elkander, indien men in de doctrina één was". ${ }^{38}$

Sy siening in verband met die kerklike seremonies was ook besonder soepel. So bv. was die vraag na die dra van 'n biskoplike kleed al dan nie vir hom geen belangrike saak nie. ${ }^{39}$ In verband met die twis oor die liturgie in die Engelse vlugtelinggemeente te Frankryk, adviseer Calvyn dat die „externi ritus” behoort tot die „mediae res", waarin verdraagsaamheid betoon moet word. ${ }^{40}$ Dit beteken nie dat Calvyn hom by ander geleenthede nie skerp uitgelaat het teen die onskriftuurlike seremonies by die Lutherane en Anglikane nie. ${ }^{41}$ In die Anglikaanse liturgie is daar "verdragelijke dwaashede", ${ }^{42}$ wat stelselmatig ontruim kan word. ${ }^{43}$

Nijenhuis vat Calvyn se eenheidsvisie konkluderend soos volg saam:

„Zelf is hij bereid geweest, inzichten, die hem zeer ter harte gingen, inzichten van theologische aard (de leer der predestinatie), van liturgische aard (de voorkeur voor sobere ceremoniën) of van kerkrechtelijke aard (de handhaving van de tucht; de leer der ambten) buiten de discussie te houden om het grote doel, de gemeenschap der evangelische kerken te bereiken".44

\section{Kritiese vrae aan Calvyn}

(1) Sit daar nie iets van 'n dualistiese en klerikalistiese kerkbegrip in die beskouinge van Calvyn nie op grond waarvan hy te veel 'n konsilie/pous met „die kerk" identifiseer, sodat die logiese konklusie hiervan moet wees: wanneer die konsilie/pous gedwaal het, dan het "die kerk" gedwaal?45

(2) Had Calvyn, by alle nadruk wat hy gelê het op die waarheid as voorwaarde en basis van die eenheid,40 wel genoegsame oog daarvoor gehad dat die éénheid self ook 'n wáarheid is? ${ }^{47}$ 
(3) Die vraag moet ook gestel word of die kerkbegrip by Calvyn nie die Koninkryksmotief oorwoeker het nie. In IV, 1, 13 maak hy Jesus se koninkryksgelykenisse (visnet, akker, dorsvloer) ongenuanseerd van toepassing op die kerk! In IV, 2, 4 identifiseer hy ook inderdaad kerk en Ryk van Christus. ${ }^{48}$

\subsection{Die ekklesiologie van W. J. Snyman}

Sonder enige twyfel het W. J. Snyman die mees omvattende en indringende studie oor die „,kerk” gemaak, in Suid-Afrika altans, en binne die Gereformeerde kerkverband. Sy opstelle oor Die gebruik van die woord ,kerk" in die Nuwe Testament ${ }^{1}$ en oor Die Kerk en sy ekumeniese roeping volgens die Nuwe Testament ${ }^{2}$ moet beskou word as van die beste wat daar in Afrikaans oor hierdie onderwerp verskyn het. Sy pragtige eksegetiese studies oor die Nieu-Testamentiese kerkbegrip is kwalik herhaalbaar, is nagenoeg uitputtend, en is van fundamentele betekenis vir alle spreke oor die ,kerk", die eenheid van die ,kerk”, en kerklike gesprek.

Ons som sy gedagtes puntsgewys op:

(1) Die N.T. spreek van die ,kerk" in tweërlei sin, nl. as plaaslike kerk en Universele KERK. Die „,kerk" bestaan nie uit gemeentes nie - want "kerk" en ,gemeente" is identies -, maar uit gelowiges. ${ }^{3}$ Elke ekklesiologiese siening wat hierdie fundamentele waarheid ignoreer, sal m.i. nimmer daarin slaag om 'n positiewe bydrae te lewer tot die kerklike gesprek nie, maar telkens verseild raak in allerlei teorieë en bespiegelinge.

(2) In sy heel eerste artikel oor die kerk word nog beklemtoon dat die eenheid van die kerk 'n „onsigbare" eienskap is, ${ }^{4}$ maar later skryf hy dat dit 'n ,ontwyking" van die vraagstuk van die eenheid van die kerk is om dit te verwys ,na die onsigbare kerk as 'n saak net van die geloof". ${ }^{\circ}$ Die kerke is een," dit is waar, maar hierdie eenheid moet ook gesien word. „Die ekumeniese roeping van die kerk bestaan derhalwe nie daarin om tot stand te bring wat nog nie bestaan nie, maar om tot uitdrukking te bring wat die kerk is en wat ons omtrent die kerk bely". ${ }^{7}$

(3) Hierdie eenheid moet o.a. tot openbaring kom in 'n Algemene Sinode oor die nasionale grense heen, sonder dat dit daardie grense hoef uit te wis. ${ }^{8}$ Dit skyn asof Snyman van oordeel is dat die Geref. Ekumeniese Sinode 'n volwaardige Sinode moet wees, omdat die kerk van Christus nie "nasionaal beperk is nie, maar die wêreld omvat". . In 'n deputaterapport wat voor die Sinode van die Geref. Kerk in S.A. gedien en waaraan ook hy gewerk het, word aanbeveel dat die G.E.S. ,sinodale status sal hê en derhalwe met gesag sal kan spreek" - al moet die onderskeie nasionale sinodes ook die besluite ,bekragtig"! ${ }^{10}$ In 'n deputaterapport wat voor die Sinode van 1949 gedien het en waarvan Snyman ook mede-opsteller was, word die vraag gestel: „Strek die kerkverband verder as nasionale en/of territoriale 
grense? - Op hierdie vraag kan op grond van die Skrif slegs ja geantwoord word. Wie gee ons die reg om die kerkverband te beperk tot sekere lande of gebiede? Is die kerk van Christus dan nie 'n wêreldkerk nie?" Daarom sou dit ,suiwer Skriftuurlik en in die lyn van die Geref. Kerkregering wees as art. 36 van die K.O. lui: Dieselfde seggenskap het die Klassis oor die Kerkraad wat die Partikuliere Sinode oor die Klassis, die Nasionale Sinode oor die Partikuliere en die Ekumeniese Sinode oor die Nasionale het". 11

(4) Daar is drieërlei vorm van kerklike eenheid: (i) gewone kerkverband; (ii) ,samewerking in soverre daar ooreenstemming is"; (iii) samespreking waar verskil bestaan". ${ }^{12}$ Ons mag egter nie berus by 'n "onvolkome kerkverband" nie maar moet dit bring tot ,groter volkomenheid". ${ }^{13}$ „Ons moet die afgedwaalde broeders en die afgedwaalde kerke opsoek. Die afgedwaalde kerke en sektes is ons vlees en bloed". ${ }^{14}$ Die kerke het die roeping ,om alles te doen om die eenheid te herstel". ${ }^{15}$

(5.1.) Die terme ware/valse kerk mag nie simplisties hanteer word nie. Dit is nie „so 'n eenvoudige saak om die valse kerk sonder voorbehoud (Calvyn) te lokaliseer nie".16 "Ons moenie dink: die antichris het die ander kerke in besit geneem en ons eie Kerk is gevrywaar teen indringing nie". ${ }^{17}$

(5.2.) Ofskoon Snyman die terminologie ,suiwer/minder suiwer kerk" aanvanklik gebruik het, ${ }^{18}$ en dit later selfs nog herhaaldelik terugkeer, ${ }^{10}$ het hy dit later tog meer krities bekyk. „Die gedeeldheid in kerkgenootskappe soos ons dit ken, is iets wat nie so moet wees nie". ${ }^{20}$ Hiermee het hy hom konkreet gedistansieer van pluraliteitsgedagte waar berusting gevra word in die verskeurde kerklike situasie.

(6.1.) Die metode wat op weg gevolg moet word, is eerstens dié van kerklike samespreking. ${ }^{21}$

(6.2.) Hierdie samespreking moet „tuis" begin word, „d.w.s. op nasionale vlak".22

(6.3.) Wat volgens ons oortuiging die regte antwoord op die ekumeniese roeping van die kerk is, moet „ook aan die Wêreldraad van Kerke voorgelê word". ${ }^{23}$

(6.4.) Die gesprek met die eenheidsbeweginge (in Afrika veral) moet gevoer word „hetsy deur die kerk, hetsy deur die A.C.B. of deur albei". ${ }^{24}$

(6.5.) Die tweede metode is dié van samewerking, ,in soverre daar samestemming is". ${ }^{25}$

(7) Rakende die basis van sodanige samesprekinge, is dit duidelik dat dit ,ruimer moet wees namate die afstand tussen die betrokke kerke groter is. ${ }^{26}$ Daar behoort geen beswaar te wees teen die basisformule van die Wêreldraad van Kerke as uitgangspunt vir 'n kerklike gesprek nie. ${ }^{27}$

\section{Kritiese vrae aan Snyman}

(1) Dit is ' $n$ vraag of Snyman terminologies daarin geslaag het 
om die Bybelse kerkbegrip konsekwent-logies te hanteer. Soms spreek hy bv. van die N.G. Kerkverband as „kerk". Persoonlik kies ek hier vir die term „kerkegroep" - 'n woord wat ons wel nie in die N.T. aantref nie, want die N.T. staan nog vóor die kerkskeuringe. Ons moet dus - tans! - onderskei tussen plaaslike kerk, Universele KERK én kerkegroepe. Lg. term word egter gebruik nié om dit te sanksioneer nie, maar ter wille van terminologiese duidelikheid en om dit uiteindelik op te ruim!

(2) Dit moet m.i. krities bevraagteken word of 'n nie-kerklike organisasie, soos bv. die A.C.B., enige kérklike eenheidsroeping besit.

(3) Die motivering vir die gesprek met kerkegroepe „wat die naaste aan ons staan", is nie altyd duidelik nie. Indien die verskeurde situasie eenmaal 'n sondige situasie is, val nie maklik in te sien waarom daar bepaalde voorkeure moet wees in die kerklike gesprek nie - soos tewens duidelik blyk uit die optrede van Calvyn, wat met élke kerkegroep ewe intens gesprekke gevoer het. Die vraag kan selfs gestel word of die noodsaak tot kerklike gesprek nie dringender word namate die kerkegroepe vérder van mekaar af is nie.

(4) Snyman gee nie 'n duidelike antwoord op die moeilike maar aktuele vraag wat daar moet gebeur ná die samespreking en samewerking nie - en hóe. Is kerklike eenheid bereik indien die onderskeie sinodes tot die konklusie gekom het dat daar geen struikelblokke in die weg is nie? Vermoedelik hang hierdie probleem saam met die feit dat die Nieu-Testamentiese kerk nog „,voor die droewige geskiedenis van kerkskeuring staan" en dat die N.T. ook ,geen direkte gegewens om tot die herstel van die eenheid te kom, bied nie".28

\subsection{Die ekklesiologie van B. Duvenage}

B. Duvenage het, sover my kennis strek, naas W. J. Snyman, in die Geref. Kerkverband in S.A. hom die indringendste besig gehou met die vraagstuk van kerklike eenheid en verdeeldheid. Daarom is dit die moeite werd om ook aan sý siening aandag te bestee. Ons gee dit kortliks soos volg weer:

(1) „Die universele Kerk kom tot openbaring waar die Woord en sakramente suiwer bedien word, of soos Calvyn dit stel, waar die hoofsom van die leer gehandhaaf word". ${ }^{1}$

(2) „Die eenheid van die Kerk is 'n eenheid van ooreenstemming in die leer van die Skrif, d.w.s. ooreenstemming in belydenis".2

(3) „Die eenheid van die Kerk word verbreek deur afdwaling van die grondslag van die eenheid, nl. die waarheid". ${ }^{3}$ Die probleem ,eenheid/waarheid" mag egter nie gesimplifiseer word nie. „Dit is 'n verkeerde dilemma om die eenheid teen die waarheid of die waarheid teen die eenheid uit te speel. Daar kan geen sprake van kerklike eenheid sonder ooreenstemming in die waarheid wees nie, maar net so kan geen kerk met die pretensie kom dat hy die waarheid besit as hy hom nie ook naarstig beywer vir die eenheid van die Kerk nie"." „Calvyn het die 
ander kerke van die Reformasie ook as ware kerke erken". (4) Dit is opvallend dat die onderskeiding "meer suiwer/minder suiwer" nêrens ' $n$ bepalende rol speel in die visie van Duvenage nie. Hy verwys byna net terloops daarna. ${ }^{6}$

(5) „Die eenheid van die Kerk word nie verbreek deur die verskeidenheid van tale nie of deur die feit dat op verskillende plekke kerke is nie". ${ }^{7}$

(6) „Die herstel van die verbroke eenheid van die Kerk lê in terugkeer na die Woord en die gemeenskaplike belydenis as antwoord van die Kerk op die Woord". ${ }^{8}$

(7) "Verskil oor seremonies wat nie die hoofsom van die belydenis raak nie, is nie genoegsame rede vir afskeiding nie".o Dit was ook die standpunt van Calvyn, ${ }^{10}$ op grond waarvan hy die gereformeerde Franse vlugtelinggemeente te Wezel adviseer om, as gaste by die Lutherse kerk, aan te pas by seremonies wat geen beslissende invloed op die belydenis van die geloof het nie. ${ }^{11}$

(8) „Afdwaling van die waarheid verbreek die eenheid en weiering om terug te keer tot die waarheid makk afskeiding noodsaaklik. So ' $n$ afskeiding is dan nie 'n verbreking van die eenheid nie, maar juis 'n voortsetting van die ware Kerk". ${ }^{12}$

(9.1.) „Dit is die roeping van die Kerk om te werk aan die herstel van die gebroke eenheid van die Kerk". ${ }^{13}$ Hierdie roeping is só belangrik dat ons soms skerp uitsprake teëkom, byvoorbeeld: „Dat die verdeeldheid van die kerke 'n ernstige probleem is wat om 'n oplossing skrei, val geensins te betwyfel nie". ${ }^{14}$

(9.2.) Daar moet begin word ,,by die kerke wat die naaste aan mekaar staan, dit wil sê by kerke binne dieselfde land of nog nader, binne dieselfde volk"..15 „Ernstige pogings moet aangewend word om die verskilpunte ((tussen die Afrikaanse kerkegroepe)) in die lig van die Skrif te ondersoek. In hierdie verband kan ons nie meer ewe maklik met die skema waar - vals opereer nie" - en dan verwys Duvenage na Calvyn se standpunt ten opsigte van die Zwingliane en die Lutherse Kerk. ${ }^{10}$

(9.3.) Die eenheidsroeping van die kerk is egter "grensloos”. Calvyn het bv. met die Roomse Kerk gespreek. „Daarom sou dit nie verkeerd wees as die Gereformeerde Kerk in Suid-Afrika ook 'n gesprek met die Roomse Kerk probeer voer nie om so die waarheid van die Skrif ook daar te laat geld nie".17 Verder „,behoort daar geen prinsipiële besware te wees teen die samespreking met Engelssprekende kerke nie. Die vraag is of die tyd nie daarvoor ryp is nie". ${ }^{18}$

(10) 'n Motief vír kerklike eenheid, wat in sy vroeëre geskrifte nie op te merk is nie, maar in sy latere wel, is die van die Koninkryk van God. Kerklike ekumene moet besien word ,vanuit die hoek van die koninkryk van God en Sy weidse perspektiewe". ${ }^{19}$ „Die koninkryksgedagte het as sentrale gedagte van die Heilige Skrif verreikende betekenis vir die kerk en daarom ook vir die ekumeniese roeping van die kerk".20

(11.1.) Die metode tot kerklike eenheid word aangedui as eerstens dié van samespreking. "Godsdiensgesprekke" — soos bv. 
Calvyn onderneem het. ${ }^{21}$ Onderlinge, on offisiële gesprekke tussen lidmate van verskillende kerkverbande kan ook geskied. ${ }^{22}$ "Samekomste van teoloë kan hiertoe ook diens doen". ${ }^{23}$ Die plaaslike kerkraad het hierin egter geen roeping nie - "so 'n samespreking raak die hele kerkverband" - maar alleen 'n meerdere vergadering. ${ }^{24}$

(11.2.) „Afgesien van samesprekings tussen geskeie kerke is samewerking ook moontlik insoverre daar'n gemeenskaplike taak is wat behartig moet word sonder om beginsels prys te gee"..25 (12) Wat moet die grondslag wees vir interkerklike samesprekings? Dit kan nie die belydenisskrifte wees nie, „omdat dit juis tussen kerke plaasvind wat konfessioneel verskil. Die grondslag kan egter die belydenis van die Bybel as die Woord van God, of van Christus as die Seun van God wees, omdat hierin die grond vir reformasie moet vasstaan". ${ }^{26}$

\section{Kritiese vrae aan Duvenage}

(1) Die hantering van die woorde (plaaslike) kerk en (Universele) KERK is by Duvenage nie Nieu-Testamenties georiënteer nie, maar fenomenologies gevul. Vgl.: „Wanneer ons Kerk met 'n hoofletter skryf bedoel ons daarmee die universele Kerk en ook die sigbare Kerkinstituut as samelewingsverband. Wanneer ons kerk met ' $n$ klein letter skryf bedoel ons daarmee kerk in denominasionele $\sin " .{ }^{27}$

(2) Duvenage dui geen konkrete en spesifieke riglyne aan wat ná die samesprekinge en samewerking moet gebeur om die kerklike eenheid te bereik nie. Sy oplossing vir eenheidsvraagstuk is vaag en dit verleen aan sy skerp kritiek op Visser 't Hooft 'n negativistiese tendens. ${ }^{28}$

(3) Hy is van oordeel dat die eenheidsgesprek gevoer moet word deur lidmate, teoloë en sinodes, maar hy toon nie oortuigend aan waarom die plaaslike kerk en kerkraad hier buite spel geplaas word nie. Die kritiese vraag moet dus gestel word of die plaaslike kerk nie ook hiérdie sónde mag bestry nie en nie ook hiérin diensbaar mag wees aan die ontplooiing van die Koninkryk van God nie.

(4) Die motivering vir die gesprek met kerkegroepe wat die „naaste" aan ons staan, is nie baie duidelik nie. Dieselfde kritiese vraag is ook aan Snyman gerig. Hierby kan nog genoem word dat dit nie altyd maklik is om te onderskei wie "naby" en wie "ver" is nie, sódanig het die kerklike toneel verskuif! Arntzen beweer bv. dat hy in 'n sekere sin meer verwant is aan die ortodokse Rooms-Katolieke gelowige as aan die progressiewe aanhanger van die Nuwe Teologie. „Misschien is Kuitert verder van huis dan de Paus!" ${ }^{29}$ „De rechtzinnig Rooms-Katolieke gelovigen staan dichter bij ons dan vele vrijzinnige protestanten". ${ }^{30}$

(5) Dit is m.i. disputabel om die dialektiese karakter van die Koninkryk van God (reeds - nog nie voltooid nie) op die kérk van toepassing te maak, ${ }^{31}$ omdat dit aanleiding kan gee tot die identifikasie van kerk en Koninkryk en tot relativering van die verskeurdeKERK-problematiek. 


\section{Diagnose}

\subsection{Die verhouding tussen die Afrikaanse kerkegroepe}

\subsubsection{Die begonne gesprek}

Ofskoon die eerste betekenisvolle besluite insake kerklike eenheid en gesprek eintlik eers op die Sinode van 1958 geneem is, is dit tog nodig om vóor te begin, en om ons probleem in historiese perspektief te plaas. En dan is die beroemde woorde van die 15 uitgetredenes te Pretoria - alhoewel dit geen kérklike uitspraak is nie - tog belangrik. Die opvallende is dat die plaaslike kerk hierin so pertinent genoem word. Hulle noem dat hulle bedroef is oor die uittreding, maar hoop en bid tog dat ,de broederliefde tusschen wederzijdsche gemeenten niet verflauwd, maar steeds meer en meer aangekweekt" mag word en dat hulle mekaar in liefde moet verdra. Hulle sluit met die gebed: „God geve dat wij nog eens allen éen worden zowel in dienst als in leer". 1

Algemeen gesproke kan ons vier fases onderskei in die gesprek wat die Geref. Kerk met die ander kerkegroepe gevoer het:

(i) Mislukte herenigingspogings tussen die Geref. Kerk en die N. H. Kerk binne die eerste twee jaar van die ontstaan van die Geref. Kerk (1859-1860).

(ii) Eerste pogings tot toenadering, 1910-1916.

(iii) Hernude pogings, 1924-1955.

(iv) Doelgerigte kontak, 1958-1970.

Gedurende die eerste twee jaar na die totstandkoming van die Geref. Kerk is daar nie minder nie as drie versoeningspogings aangewend om die breuk met die N. H. Kerk te heel. Die Gereformeerdes het egter onwrikbaar daarop gestaan dat alleen in 'n terugkeer na die leer, diens en tug soos by Dordrecht (1618-1619) vasgelê, enige moontlikheid tot hereniging geleë is. Hulle wou van harte met hulle naaste verenig, maar dit moet met Gods Heilige Woord ooreenkom, anders durf hulle dit nie waag nie. ${ }^{2}$

Die Sinode van 1869 neem die besluit dat uit die „bedorwe Kerkgemeenschap" (van die N.H.K. in Transvaal) uitgetree is omdat dit geblyk het die "valse kerk" te wees. ${ }^{3}$ Hieruit is onder meer duidelik dat die aanvangsjare vol spanning was.

Die interessante is dat die pogings tot toenadering ook vanuit die N.G.K. en N.H.K. gekom het. Op die Sinode van 1910 dien 'n brief van ds. Paul Nel, skriba van die N.H. of G. Kerk in Transvaal, waarin gevra word dat die Geref. Kerk 'n kommissie moet benoem om 'n kommissie van die N.H./G. Kerk te ontmoet insake toenadering tussen die Kerke. Die Geref. Kerk antwoord dat indien die N.H./G. Kerk volmondig instem met ons Openlike Verklaring die benoeming van sodanige kommissie oorweeg sal word. ${ }^{4}$ Ds. Nel antwoord - aan die Sinode van 1913 - dat die Verenigde Kerk hom grond op dieselfde beginsels soos vervat in die Openlike Verklaring en dat 'n ontmoeting met die oog op toenadering gereël moet word. Hierop benoem die Sinode van die G.K. 'n kommissie. ${ }^{5}$ Die twee kommissies ontmoet en 
die Verenigde broeders lê 'n besprekingsprogram voor waarin o.a. vermeld word dat die doel van die samewerking van die twee Kerke kerkvereniging moet wees, sodat dit een volk en een kerk kan wees. Die Geref. kommissie is egter van oordeel dat die gedagte al sou die Hollandssprekende bevolking maar een kerk mag hê, geen rekening hou met die loop van die historie in die ontstaan van die kerke nie en ook nie met die amp van die gelowiges in elke plaaslike gemeente om te waak vir die kenmerke van die ware Kerk, en dat daarom die samewerking van alle gelowiges in een kerklike liggaam nie deur kunsmatige samebinding tot stand moet kom nie. Teen gemeenskaplike optrede is egter geen beswaar nie. Die Sinode van 1916 keur hierdie standpunt goed en kies dus daarmee min of meer vir die pluraliteitsgedagte. ${ }^{0}$ Hiermee het hierdie gesprek ook tot 'n einde gekom.

Op die Sinode van 1924 dien egter 'n beskrywingspunt van die kerkraad van die G.K. Bloemfontein waarin die Sinode versoek word om 'n kommissie van 6 lede te benoem ,om namens die Gereformeerde Kerk en in samewerking met ander Hollandse Kerke in sosiale aangeleenthede te handel". Die Sinode benoem toe ingevolge art. 49 K.O. deputate - t.w. die betrokke kerkraad - vir korrespondensie met binnelandse kerke. ${ }^{7}$ Op die Sinode van 1927 word gerapporteer dat geen korrespondensie gevoer is nie en 'n nuwe deputaatskap word benoem in die persoon van ds. D. Postma. ${ }^{8}$

Ondertussen het die gedagte van 'n Gereformeerde Ekumeniese Sinode, soos geinisueer deur die Geref. Kerk in S.A., ${ }^{9}$ sterker op die voorgrond getree. En juis in verband met die G.E.S., of „Internasionale Sinode" soos dit destyds genoem is, ${ }^{10}$ het die kontak met die ander twee Afrikaanse kerkegroepe ter sprake gekom. 'n Sinodale kommissie het geadviseer dat ,ook die ander twee Hollands-Afrikaanse Kerke" vir samewerking genader moet word, ${ }^{11}$ maar die Sinode het die saak nie afgehandel nie. ${ }^{12}$

Op die Sinode van 1936 tree 'n nuwe wending in toe 'n brief van ds. L. E. Brandt, voorsitter van die kommissie van die Algemene Kerkvergadering van die N.H.K., behandel word waarin o.a. vermeld word ,de mogelijkheid van de stichting van een interkerkelijke commissie ter behartiging van de gemeenschappelijke belangen der Hollandsche Kerken", ${ }^{13}$ warop die Sinode G.K. positief reageer en twee afgevaardigdes hiervoor benoem, maar op voorwaarde dat die adviese van die Interkerklike Kommissie (I.K.K.) nie as bindend beskou sal word nie. ${ }^{14}$

Op die Sinode van 1939 rapporteer die deputate dat die eerste samespreking van die I.K.K. in 'n "hartlike, broederlike gees" in Bloemfontein plaasgevind het op 14 Maart 1939, maar dat hulle met „diep teleurstelling” daarvan kennis geneem het dat geen afvaardiging van die N.H.K. - wat eerste die versoek tot die daarstelling van 'n I.K.K. gerig het - teenwoordig was nie.15 Uit die Acta is dit duidelik dat die Sinode G.K. met die saak geworstel het.10 In die Reglement van die I.K.K. staan dat die Kommissie ook moet dien ,tot bevordering van die onderlinge stigting en opbouing, en tot nouere toehaling van die broederband". ${ }^{17}$ Die I.K.K. beveel ook aan 
dat in die toekoms die verskillende Sinodes adviserende deputate na mekaar sal stuur. ${ }^{18}$ Verskeie sake - met die oog op samewerking is op die I.K.K. behandel, o.a. volksverdeeldheid, kerklike tug, sektewese. Die Sinode G.K. is bereid tot samewerking waar moontlik en nodig. ${ }^{10}$ Die vraagstuk van die mandaat van die deputate op die I.K.K. kom ook ter sprake - soos later telkens weer - maar dit word nie gefinaliseer nie. ${ }^{20}$

Ook op die Sinode van 1942 word gerapporteer dat daar geen offisiële afvaardiging van die N.H.K. op die eerste voortgesette byeenkoms van die I.K.K. teenwoordig was nie. ${ }^{21}$ Die I.K.K. benoem egter 'n studiekommissie om te rapporteer oor hoe „tussenkerklike samewerking op 'n gesonde basis bevorder kan word; byvoorbeeld oor die vraagpunte in verband met die verhouding tussen die HollandsAfrikaanse kerke onderling ..." ${ }^{22}$ Op die tweede vergadering van die I.K.K. is ds. T. F. Dreyer van die N.H.K. teenwoordig en hy noem die rede vir afwesigheid van die N.H.K.: „die nie-erkenning van die Herv. Kerk deur die ander Afrikaanse Kerke as 'n susterskerk" - selfs die bestempeling as "valse kerk".23 Die Sinode G.K. besluit dat die G.K. „reeds in die praktyk bewys bet dat hy beide die Ned. Geref. Kerk en die Ned. Hervormde Kerk erken as Christelike kerke" en dat hy ,graag broederlike verhouding en hartlike samewerking wil onderhou sowel met die Ned. Geref. as met die Ned. Herv. Kerke". „Die Sinode spreek nou verder uit, dat die Geref. Kerk graag Korrespondensie met die ander twee Hollandse Kerke wil onderhou". ${ }^{24}$ Oorleg moet ook gepleeg word met die N.G.K. en N.H.K. in verband met die G.E.S.25

Op die 1943-sitting van die I.K.K. was die Hervormde broeders teenwoordig „,sodat die drie Afrikaanse Kerke vir die eerste keer saam was" - waaroor die Sinode G.K. hom grootliks verbly het.26 Die sinodale deputate bring die besonder belangrike saak ter sprake nl. dat die Sinode hom moet uitspreek oor "die vorming van plaaslike interkerklike komitees", 27 'n vraag wat die Sinode egter volkome ignoreer. ${ }^{28}$ Die I.K.K., waaronder ook die deputate van die G.K., het besluit dat ,die sondige toestand van kerklike gedeeldheid in die boesem van ons Boerevolk, gevoel, bely en bestry moet word, sodat die breuk in die waarheid en in die liefde geheel kan word". Voorts moet die Kerke ,'n onderlinge atmosfeer van liefde en ver. troue skep", waardeur onder meer die weg ,voorberei sal word vir 'n al nouer kerklike samelewing en samewerking". ${ }^{29}$ Hierdie voorstel tot „verbondsluiting" tussen die 3 kerkegroepe word nie deur die Sinode om prinsipiële redes verwerp nie, maar daar word besluit „dat die tyd vir hierdie saak nog nie ryp is nie". ${ }^{30}$

Die Sinode van 1949 behandel 'n breedvoerige rapport insake die G.E.S. Interessant is in hierdie verband dat die deputate ook navraag gedoen het by „Engelse Kerke” in verband met samewerking in die G.E.S. Die antwoorde van die Presbyterian Church of S.A. en die Church of England in S.A. was positief, maar dié van die Congregational Union in S.A., die Methodist Church of S.A. en die Baptist Union of S.A. was minder entoesiasties. ${ }^{31}$ Die Sinode besluit dan ook met e.g. twee kerkegroepe te onderhandel met die oog op die 
G.E.S., en voorts dat die 4 gefedereerde N.G. Kerke en die N.H.K. na die G.E.S. uitgenooi sal word.$^{32}$ Die Sinode neem met groot vreugde kennis van die positiewe antwoorde van die 4 N.G. Kerke en die 2 Engelse Kerke. „Ons glo in die een heilige algemene Christelike Kerk. Dit stel ons voor die heilige roeping om die eenheid ook in die uitwendige te soek in steeds wyer verband altyd op die vaste grondslag van die waarheid". ${ }^{33}$ Die deputate van die „Tussenkerklike Kommissie" (= I.K.K.) rapporteer dat hulle twee keer vergader het en saamgespreek het oor 0.a. gesamentlike dankdienste na die oorlog, segregasie, kerklike oorgang, interkommunie ens. ${ }^{34}$ Die I.K.K. noem dat die 3 Hollands-Afrikaanse Kerke „mekaar erken as geëerde susterkerke in die Here". ${ }^{35}$

Opvallend is dat op die Sinode van 1952 berig word dat slegs die Church of England in S.A. uitgenooi sal word deur die G.E.S., ${ }^{36}$ alhoewel ons Sinode sy kontak met die Presbyterian Church of S.A. voortsit. ${ }^{37}$ Die deputate van die Tussenkerklike Kommissie (T.K.K.) berig dat hulle weer vergader het. Die T.K.K. beveel aan ,dat die oorgaan van lidmate van een Kerk na ' $n$ ander sal geskied na die volste broederlike raadpleging tussen die betrokke kerkrade". ${ }^{38}$ Interkommunie „moet nie aangemoedig word nie" maar daar kan „uitsonderingsgevalle" wees waarby volgens kerkorde gehandel moet word. ${ }^{30}$ Die ,susterskerke" moet "steeds in voeling met mekaar bly" en daar moet ,gesoek word om die bande tussen die betrokke Kerke steeds nouer aan te haal". ${ }^{40}$ Die besluite van die T.K.K. wil ,,alleen van adviserende aard" wees.41 Ds. I. D. Kruger meen 'n „beweging tot Kerkherstel" te bespeur.42 Die Sinode besluit om 'n deputaatskap te benoem ,om 'n deeglike studie te maak van die interkerklike verhoudinge”, terwyl hulle ook sal rapporteer ,insake die mandaat van die deputate op die Tussenkerklike Kommissie"..43 Vermelding verdien miskien ook dat in die rapport van die Deputate vir die Bestryding vir Sosiale Euwels genoem word dat in Johannesburg 'n „Skakelkomitee van Christelike Kerke in Transvaal" gestig is (1950), bestaande uit 4 verteenwoordigers van die Engelse Kerke van Transvaal en 4 van die Afrikaanse Kerke van Transvaal, met die doel om sosiale euwels te bestry. ${ }^{44}$ Die Sinode neem „met dankbaarheid kennis" hiervan en hoop op 'n „kragtige eenheidsoptrede" teen ,die magte van die duisternis"..45

Die bewoënheid ten opsigte van die eenheid van die KERK het by sommige broeders teen 1955 so hoog gevlam dat 'n kommissie by die Sinode aanbeveel dat aansluiting by die Wêreldraad van Kerke (W.R.K.) oorweeg moet word ten einde ons ,getuienis" daar te laat hoor en omdat sodoende die 9 kerke in S.A. wat reeds lidkerke was, as „behoudende element" versterk sal word ${ }^{40}$ - 'n voorstel wat egter verwerp is. ${ }^{47}$ Besonder belangrik is die afvaardiging van 'n rapport van W. J. Snyman oor ,korrespondensie in enger sin" (= een wêreldwye kerkverband van Gereformeerde kerke) en ",korrespondensie in ruimer sin" (met min of meer verwante kerke in verskillende kerkverbande). ${ }^{48}$ Ten opsigte van die vraagstuk van oorkoms na die G.K., verwys die Sinode na 'n besluit van 1873 (art. 182), waarin bepaal word dat die volle kerkraad of 'n kerkraadskommissie 
sodanige(s) moet ondersoek "oor die redes van sy oorkoms".40 Hiermee is die vraagstuk egter net gedééltelik opgelos en is nie geantwoord op die vraag na die oorgang van 'n Geref. lidmaat na 'n ander kerkverband en die verhouding tussen die twee betrokke kerkrade nie. Die sinodale besluit insake interkommunie is nog meer onbevredigend, aangesien net verwys word na art. $61 \mathrm{~K} .0 .{ }^{50}$ Hierin word vermeld dat iemand uit 'n ,,ander kerk" nie tot die nagmaal toegelaat mag word nie tensy hy getuienis het dat hy belydenis gedoen het van die „Gereformeerde Godsdiens". Die hele problematiek van interkommunie, veral by verskeurde Geref. kerkegroepe, word nie in art. 61 opgelos nie, tewens, toe die K.O. opgestel was, wás die Geref. Kerke nog één - die verbrokkeling hiervan het eers in die negentiende eeu begin. Die Sinode keur goed dat die naam deurgaans nie Tussenkerklike Kommissie nie maar Interkerklike Kommissie sal wees. ${ }^{51}$ In die vervolg sal die Sinodale Deputate vir Korrespondensie uit hulle midde persone aanwys om op die I.K.K. te dien en daar sal in die toekoms geen aparte deputate meer benoem word nie.52 Hulle mandaat is baie wyd en vaag, nl. „om samewerking te verkry in verband met voorvallende sake waar die eer van God eis dat die Kerke gesamentlik sal optree ter verdediging daarvan" (Sinodale besluit 1930, art. 130). ${ }^{53}$ Die Sinode verwerp 'n aanbeveling van die deputate van die I.K.K. waarin versoek is dat die I.K.K. omskep sal word in 'n Adviserende Raad van Afrikaanse Kerke wat sal dien as aksiekomitee vir die onderskeie Sinodes, as 'n buro vir interkerklike advies vir optrede in ekumeniese aangeleenthede. ${ }^{31}$ In verband met 'n beskrywingspunt van die Klassis Reddersburg dat die Sinode hom uitspreek „oor dienste wat gesamentlik met ander kerke gehou word", ${ }^{\circ 5}$ beveel 'n kommissie aan dat "dergelike godsdienstige samekomste waarin ons as Afrikanervolk ons voor die aangesig van God stel, verwelkom moet word".56 Die Sinode neem egter geen besluit hieroor nie maar ,dra die saak op aan die deputaatskap vir Korrespondensie om hierdie aangeleentheid op die Interkerklike Kommissie broederlik te bespreek". ${ }^{\text {.7 }}$

Die besluite van die Sinode van 1958 is vir 'n juiste siening van die eenheidstrewe van die G.K. van bepalende betekenis. Prof. W. J. Snyman beveel aan dat "ons eerw. Sinode dit ernstig oorweeg om met die ander Afrikaanse kerke en m.n. Die Nederduitse Gereformeerde Kerk van Suid-Afrika te kom tot amptelike samesprekinge met die oog op wat die Kerke uitmekaar hou en met die oog op ons roeping om nie te berus by die gedeeldheid van kerke nie". 88 'n Soortgelyke beskrywingspunt van die Part. Sinode O.V.S. en Natal dien ook op die Sinode. ${ }^{59}$ 'n Kommissie doen tydens die Sinode verslag, wat in sy geheel aanvaar word, met W. J. Snyman as rapporteur. ${ }^{00}$ Drie sake word hierin genoem:

(i) 'n Afwysing van élke kerklike absolutisme (die eie kerkformasie is die ,alleenware kerk").

(ii) 'n Afwysing van die pluriformiteitsleer wat leer dat die veelheid van kerke ' $n$ feit is om in te berus. 
(iii) Aanvaarding - saam met Calvyn - dat nie berus kan word in die veelheid van kerke nie.

„Die eenheid van die uitwendige kerk is 'n goddelike eis en opdrag". ${ }^{81}$ Hieruit volg dat dit wat uitmekaar hou, broederlik onder oë gesien moet word "om sodoende te bring in een kerkverband". ${ }^{02}$ Ter motivering van waarom enger korrespondensie aangebied word aan The Reformed Churches of New Zealand noem die Sinode: eenheid in „,belydenis, kerkorde en liturgie". ${ }^{83}$

Op die Sinode van 1961 word gerapporteer dat die T.K.K. (die goedgekeurde naam van I.K.K. funksioneer al weer nie!) vergader het en samesprekings gevoer het met die 1958-besluit van die Sinode G.K. as basis. 'n Beskrywingspunt van die Klassis Krugersdorp, toegelig deur B. Duvenage, dien ook op hierdie Sinode waarin die Sinode onder meer versoek word om te besin „om korrespondensie in enger sin met behoudende Engelssprekende Kerke te voer"..8 Die Sinode het egter hierdie suggestie geïgnoreer. ${ }^{\circ 0}$

Op die Sinode van 1964 dien, soos gebruiklik, twee rapporte, nl. oor „Ekumeniese Sake" ${ }^{\circ 7}$ en oor "Samespreking met ander kerke".08 Die bevindinge van eg. ${ }^{09}$ is egter ook vir lg. belangrik, selfs al het alle bevindinge nie sinodale besluite geword nie. In die bevindinge word o.m. onderskei tussen 'n Skriftuurlike verskeidenheid van kerke (m.i. die régte soort pluriformiteit) en 'n sondige geskeidenheid (m.i. te noem pluraliteit).$^{70}$ Die metode wat gevolg moet word om die sondige geskeidenheid teen te gaan, is dié van samespreking en waar moontlik samewerking. ${ }^{11}$ In die tweede rapport, $\mathrm{nl}$. oor interkerklike samesprekinge, meld die deputate dat daar ,in geen opsig oorhaastig opgetree moet word nie", dat hulle "langsaam haas" en nog "verkenningswerk" doen. ${ }^{72}$ Ons beluister egter die ongeduld van die Sinode wanneer besluit word om teen 1967 ,iets meer konkreets" van die deputate te verneem. ${ }^{73}$ Daar word ook besluit dat die Sinode hom op grond van Skrif en Belydenis ,distansieer" van 'n eenheidsbeweging soos die Christelike Instituut in Suidelike Afrika. ${ }^{74}$ Besonder belangrik is ook dat interkommunie nou in die nuwe geredigeerde Kerkorde eens en vir altyd onmoontlik gemaak word, aangesien die nuwe redaksie van art. 61 lui dat ,sonder sodanige getuienis moet ook diegene wat uit ander kerke (van dieselfde kerkverband) kom, nie toegelaat word nie". ${ }^{75}$

Die Sinode van 1967 behandel ook twee rapporte: een oor ,Ekumeniese Sake" ${ }^{76}$ en een oor "Samespreking met ander kerke".77 Ook hiér is eg. rapport vir ons onderwerp van belang. Wat hiérin opval, is dat o.a. die stelling dat die Konfessies ,geen radikale skeiding ken tussen die sg. sigbare en onsigbare kerk nie: die oorgang is bv. in N.G.B. XXVII-XXIX besonder vloeiend". ${ }^{78}$ Die metode om die verbroke eenheid te herstel, is die van amptelike samesprekinge op grond van die Woord van God.79 Die volle belydenis kan nie as uitgangspunt geld nie en wás ook nie die uitgangspunt van die godsdiensgesprekke tussen die teoloë en kerke tydens die Reformasie nie.80 Ons mag ander kerke ook nie "sonder meer as valse kerke bestempel" nie. ${ }^{81}$ Die "samevatting" ${ }^{82}$ van hierdie deputate-rapport 
word deur die Sinode aanvaar as „voorlopige riglyne vir die ekumeniese roeping van die kerk". ${ }^{33}$ Die tweede rapport - oor interkerklike samespreking -, waarin breedvoerig gehandel is oor die kerkbegrip van die N.G.K., ${ }^{84}$ en waarin kollegialistiese tendense aangestip is, is deur die Sinode ,as 'n basis van samespreking met die Ned. Geref. Kerk" aanvaar. ${ }^{80}$ In hierdie memorandum vir samespreking word o.a. beweer dat „waar 'n denominasionele verdeling van kerke onder een volk bestaan, moet alles gedoen word om die eenheid te herstel op grond en ter wille van die eenheid van die kerk van Christus". ${ }^{80}$ Die Sinode word versoek om die mandaat van die deputate insake samesprekings met ander kerke sodanig uit te brei „dat die opdrag ook 'n interkerklike gesprek sal behels met ander kerke as slegs die twee Afrikaanse kerke". Aan die te benoeme deputate moet opgedra word om die Sinode te adviseer „oor met watter kerk en waaroor 'n gesprek geopen moet word". ${ }^{87}$ Met hierdie besluit het die Sinode dus sy eenheidshorison enigsins verbreed.

Op hierdie Sinode kom ook 'n nuwe faktor in die eenheidsgesprek na vore. 'n Plaaslike kerkraad - Johannesburg-Sentraal - deel die Sinode mee dat hy reeds vanaf 1964 ,'n gesprek voer met die kerkraad van die N.G. Kerk Johannesburg (Braamfontein)" en dat 'n kwartaalblad - Kruispunte - uitgegee word.88

Op die Sinode van 1970 rapporteer die Deputate vir Samespreking met ander kerke $^{8 \theta}$ dat die „kernpunt" van die voortgesette samesprekinge met die ander twee kerke gegaan het oor ,die verband tussen die onsigbare en die sigbare kerk met betrekking tot die eenheid van die kerk". ${ }^{00}$ Hulle meld voorts dat hulle "nog nie so ver gevorder het dat advies uitgebring kan word met watter kerke, behalwe die N.G. en N.H. Kerke, 'n gesprek gevoer behoort te word nie". ${ }^{01}$ Die belangrike aankondiging word gedoen dat ,'n memorandum ((deur die deputate van die drie Afrikaanse kerkegroepe)) opgestel sal word waarin die punte van ooreenstemming en die punte van verskil duidelik omlyn word". ${ }^{22}$ Die Sinode neem 'n - m.i. besonder eienaardige - besluit, nl. om hom nie uit te spreek oor ,die Geref. Kerk se beskouing oor die kerk" nie, ${ }^{93}$ want (i) hoe kan daar met ánder kerkegroepe oor die kerkbegrip gepraat word as daar sélf nie eers duidelikheid is nie?; en (ii) die Sinode gee dan juis opdrag tot voortgesette gesprek ,op die basis soos goedgekeur deur die Sinode van 1967"! 94 'n Belangrike en verhelderende besluit is egter dat voortaan” álle ekumeniese sake” na „Deputate vir ekumeniese aangeleenthede" verwys sal word. ${ }^{\circ 5}$

Hierdie Sinode het ook 'n aantal adviese van die G.E.S. van 1968 goedgekeur wat van groot belang is vir die interkerklike gesprek in S.A. „Die eenheid van die Gereformeerde Kerke moet gesien word as ons dringendste en belangrikste ekumeniese roeping". ${ }^{86}$ "Ledekerke van die G.E.S. in ' $n$ bepaalde streek moet kragtig aangespoor word om die ekumeniese gesprek aan te gaan en ongeregverdigde skeidinge te heel”. ${ }^{97}$ „,Kerke wat in die G.E.S. deel, moet aangemoedig word om verskillende soorte kontak met ander Christelike kerke te bewerkstellig, beginnende met kerke wat Gereformeerd is in belydenis en tradisie". ${ }^{88}$ 
Op dieselfde Sinode waartydens goedgekeur is om "verskillende soorte kontak" met ander Christelike kerke te bewerkstellig, word die ingrypende besluit geneem dat ,geen offisiële samesprekings intussen ((dit is terwyl die sinodale deputate daarmee besig is)) op plaaslike vlak daaroor sal plaasvind nie" aangesien die verhouding tussen kerkegroepe die „belydenis en kerkregering” raak, en bowendien is volgens die Openlike Verklaring die weg terug na die G.K. altyd oop! ${ }^{\prime \bullet}$

Dít wat betref die interkerklike samesprekinge.

Ten opsigte van die interkerklike samewerking is daar ook al baie belangrike werk verrig, ofskoon hierdie werk nie altyd doelbewus afgestem was op kerklike eenheid nie. Ons dink bv. aan die groot werk van die Bybelvertaling, die Psalmberyming, die vertaling van die Formuliere van Eenheid en Liturgiese Formuliere, die werk aan die Bybel met Verklarende Aantekeninge. ${ }^{100}$ Ook op die gebied van die sending is al saamgewerk. Die Sinode van 1958 het bv. goedgekeur ,dat ons Kerk sover moontlik en sonder om ons ((sending-)) terrein of lidmate in gevaar te stel, met die ander Afrikaanse kerke sal saamwerk. Dit geld sowel die besetting van nuwe gebiede asook die samewerking insake die vertaling van belydenisskrifte, formuliere ens." 101 „Ongesonde kompetisie" by die besetting van nuwe sendingterreine moet tussen die drie kerkegroepe uitgesluit word.102 Ten opsigte van evangelisasie dink ons veral aan die 1967-besluit waarin met aanbeveling na die plaaslike kerkrade verwys is die gesamentlike „,doeltreffende kerklike sensusopname" deur die drie Afrikaanse kerkegroepe, veral in stedelike gemeentes. ${ }^{103}$ Noemenswaardig is miskien ook die werk van die verskillende Teologiese werkgemeenskappe - wat wel onoffisieel geskied, maar is die beoefening van Teologie nie 'n kérklike saak nie?

Hierdie historiese oorsig is geskryf vanuit die gesigspunt van die G.K. Vanselfsprekend kan dit ook gedoen word vanuit die visies van die N.G.K. en N.H.K. Persoonlik meen ek veel meer openheid en bewoënheid ten opsigte van die eenheid van die KERK by die N.G.K. as by die N.H.K. op te merk. Die fiasko na Cottesloe (1960) het die eenheids-engagement van die N.H.K. 'n gevoelige knou toegedien sodat prof. A. D. Pont (en ek weet dat hy nie die N.H.K. uitmaak nie) dankbaar daaroor kan skryf dat die ,invloed van die sogenaamde ekumeniese teologie in ons Kerk tot ' $n$ nulpunt gedaal het". ${ }^{104}$ Die N.G.K. is 0.a. betrokke by sowel die G.E.S. as die Wêreldalliansie van Gereformeerde Kerke, die N.H.K. net by lg.

\section{Kritiese vrae aan die Sinode}

(1) Dit kan nie betwyfel word nie dat daar meermale 'n groot huiwering by die Sinode was wanneer oor die eenheids-problematiek gehandel is, wat ook bewys word deur die feit dat daar 'n duidelike koerswysiging ingetree het sedert 1916, toe die pluraliteitsgedagte min of meer aanvaar is, en 1958, toe dit radikaal verwerp is.

(2) Die kritiese vraag moet gestel word of daar wel 'n sinvolle gesprek gevoer kan word oor die kerkbegrip van ánder kerkegroepe, terwyl daar sélf nog nie volkome duidelikheid is nie. 
(3) Behoort die diskussie eerstens te gaan oor die kerkbegrip - waaroor self nog geen duidelike besluit geneem is nie! - of oor die kardinale vraag in verband met die interpretasie van die $\mathrm{Be}$ lydenisskrifte, nl. hoe dit moontlik kan wees dat kerkegroepe met presies dieselfde Belydenisskrifte, binne een en dieselfde volk, tog kon skei en apart kan bly voortbestaan.

(4) Die byhaal van kerkorde en liturgie in die eenheidsgesprek is nie in ooreenstemming met die visie van die Reformatore, i.c. Calvyn, nie. Dit is tewens ' $n$ dualistiese standpunt om enersyds in ekumeniese verband die standpunt te huldig dat „,because of the diversity in the forms of government of the Reformed Churches, uniformity of church polity cannot be stressed as a fundamental requisite",105 terwyl dit andersyds besonder skerp van toepassing gemaak word op die kerkegroepe in Suid-Afrika.

(5) Die relativering van die roeping van die plaaslike kerk in verband met die eenheidsgesprek kan maklik uitloop op die relativering van die selfstandigheid van die plaaslike kerk en 'n sinodokratisering van die eenheidsroeping van die Sinode. ${ }^{106}$

\subsection{2. ' $n$ Kernprobleem}

Wat is een van die kernprobleme in die verskeurde kerklike verhoudinge onder die drie Afrikaanse kerkegroepe. Die probleem is m.i. nie eerstens daarin geleë dát daar verskil is in kerkregering en liturgie nie, maar die probleem gaan dieper: Hoe is dit moontlik dat drie kerkegroepe binne dieselfde volk, met presies dieselfde taal, en MET PRESIES DIESELFDE BELYDENISSKRIFTE, waarin sekere kerkregtelike (N.G.B. artt. 30-32) en liturgiese beginsels (H.K. 35 en 38) vervat is, kon ontstaan het en nog apart kan bly voortbestaan?" Gewoonlik word beweer dat „,kerke eers één in Belydenis moet wees voordat daar sprake van 'n kerkverband kan wees". ${ }^{2}$ Hierdie stelling klop egter nie. Unanieme Belydenisskrifte garandeer nie die eenheid van die KERK nie, selfs nie met 'n qiua-standpunt nie. En dit om drie redes.

Eerstens tref ons vandag kerkegroepe aan met presies dieselfde Belydenisskrifte maar wat volkome apart en verskeurd langs (en soms téenoor) mekaar bestaan - soos bv. die drie Afrikaanse kerkegroepe. (Ons dink ook daaraan dat die Rooms-Katolieke Kerk en Reformatoriese kerkegroepe almal die Apostolicum aanvaar).

Tweedens is daar kerkegroepe wat nié dieselfde Belydenisskrifte besit nie, bv. die G.K.S.A. met sy drie Formuliere van Eenheid, en die Free Church of Scotland met sy Westminsterse Konfessie, maar wat wél in enger korrespondensie (kerkverband) staan.

Derdens het ons tans die besonder eienaardige situasie dat die G.K.S.A. veel nader staan aan die N.G.K. met wie hy nié in enger korrespondensie is nie, as aan die G.K. Nedl. met wie hy wêl in enger korrespondensie is. (Al drie kerkegroepe het dieselfde Belydenisskrifte).

Dit beteken dat ons enersyds rekening moet hou daarmee dat die Belydenisskrifte vatbaar is vir verskillende interpretasie en dat dit 
'n faktor is wat kan uitloop op kerkskeuring. ${ }^{3}$ Andersyds word ons genoodsaak om 'n onderskeiding te maak tussen „Belydenis” en „Belydenisskrifte". Kerkegroepe kan verskillende Belydenisskrifte besit maar tog dieselfde Belydenis en dus één wees, soos bv. die geval met die G.K.S.A. en die Free Church of Scotland. Daar kan egter nooit sprake van eenheid wees as daar verskil in Belydenis is nie. Om dit te ontdek, moet ons deurstoot na die skopus van die N.T. En dit is m.i. niks anders nie as dat die Koninkryk van God gekom het met die koms van Jesus van Betlehem en die uitstorting van die Gees van God, en dat die Jode opgeroep word tot die belydenis: „Jesus is die Messias" (Matt. $16: 16,1$ Joh. $2: 22$ ) en die heidene tot: „Jesus is die Kurios” (Rom. 10:9, 1 Kor. $12: 3$, Filipp. 2 : 11). So 'n „,basis" lyk op die oog af dun, maar tog staan of val die KERK daarmee. ${ }^{4}$ Dit is nie 'n ,gereduseerde" Belydenis nie, ${ }^{5}$ maar 'n Belydenis wat direk uit die N.T. opkom en waarsonder die KERK nie vir een enkele oomblik kan bestaan nie. Dit beteken nie dat daar geen uitgebreider Belydenis mag ontwikkel nie (vgl. Filipp. $2: 6-11$ ), maar dan altyd rondom hierdie kern. Wanneer daar tans ook stemme opgaan vir reduksie van die Belydenisskrifte, ${ }^{\circ}$ dan moet daar baie duidelik onderskei word tussen formele en materiële reduksie. Dit is seker moontlik om in 'n eventueel nuwe Belydenisskrif formeel alles korter te stel - en ook 'n klomp nuwe ketterye te weerlê as wat in die 3 Formuliere geskied het, sonder om iets van die materie verlore te laat gaan.

Hiermee hang saam die vraag na die toelaatbare konfessionele ruimte. Dit kan bv. nie ontken word nie dat „de legitieme pluraliteit van de leer in die vroege kerk aanzienlijk groter was dan in de latere". ${ }^{7}$ Calvyn was bereid om te Strassburg die wederdoper Hermannus in die kerk op te neem al had lg. nog probleme met die uitverkiesing. ${ }^{8}$,Onder leiding van de tegenwoordige prof. Schilder werd in de Vrijgemaakte kerk van Utrecht een ouderling bevestigd - hij werd later predikant - die zich niet kon verenigen met de Dordtse leerregels 3/4, 14". ${ }^{\text {' }}$ 'n Behoudende figuur soos dr. M. J. Arntzen ag dit „echt niet erg als iemand b.v. bezwaren heeft tegen de kinderdoop" - solank hy dit net nie propageer nie.10 Die vraag ontstaan dus waaroor alles 'n legitieme verskil mag bestaan maar waardeur die eenheid van die KERK nie in gevaar gebring word nie.

Die vraag of 'n nuwe Belydenisskrif - bv. 'n Confessio Africana - enige betekenisvolle bydrae kan lewer tot groter toenadering tussen die drie Afrikaanse kerkegroepe, moet met nee en ja beantwoord word. Nee, omdat die bestaande situasie getuig dat ons, ondanks eenvormige Belydenisskrifte, tog as aparte kerkegroepe kan bly voortbestaan, en ja, omdat die opstel van sodanige Belydenisskrif asook die Belydenisskrif sélf moontlik 'n positiewe uitwerking ten gunste van kerkeenheid sal kan uitoefen. ${ }^{11}$

Die kernvraag bly egter: Wát - of wie - garandeer kerkeenheid? En hoé vind ons mekaar ooit weer terug ?12 
2.2. Die verhouding tussen die Afrikaanse en Engelse kerkegroepe ${ }^{1}$

\subsubsection{Rakelingse kontak}

Ons het reeds in die verbygaan gewys op die vlugtige kontak wat met die Engelse kerkegroepe in S.A. gemaak is. 'n Ope vraag is of die politieke geskiedenis in Suid-Afrika nie hierin 'n groot rol gespeel het nie - en nóg speel.

Ons het daarop gewys dat die Sinode van 1947 besluit het om verder te onderhandel met die Presbyterian Church in S.A. en die Church of England in S.A. met die oog op die G.E.S. Die Sinode van 1952 weer het met dankbaarheid kennis geneem van die "Skakelkomitee van Christelike Kerke in Johannesburg" ter bestryding van sosiale euwels en waarby 4 verteenwoordigers van die Engelse kerkegroepe ingeskakel was. Die Sinode van 1961 ignoreer egter 'n beskrywingspunt waarin gevra word om te besin oor korrespondensie in enger sin met behoudende Engelssprekende kerkegroepe. Die Sinode van 1967 besluit dat die interkerklike gesprek met meer kerkegroepe as net die 2 Afrikaanse gevoer sal word, en dat die deputate die volgende Sinode hieromtrent sou adviseer - iets wat op die Sinode van 1970 nie verder gevorder het nie en dus in die toekoms nog verdere aandag sal moet geniet.

Van werklike indringende kontak en skakeling op sinodale vlak tussen die G.K. en die Engelse kerkegroepe was en is daar dus nie sprake nie. ${ }^{2}$ Hoogs waarskynlik geld dit ook van die verhouding tussen die N.G.K. en N.H.K. enersyds en die Engelse kerkegroepe andersyds.

\subsubsection{Probleme}

Die verhouding tussen die G.K. en die Engelse kerkegroepe is om die volgende redes gekompliseerd:

(1) Hulle besit verskillende Belydenisskrifte, terwyl sommige glad nié Belydenisskrifte besit nie, soos bv. die Baptist Union in S.A. ${ }^{3}$ Die Church of the Province in S.A. het blykbaar ook geen spesifieke simbole nie, terwyl die Church of England in S.A. (die meer behoudende van die twee Anglikaanse kerkegroepe), nog die 39 Articles besit. ${ }^{4}$ Die Presbyterian Churches in S.A. het naas die ekumeniese simbole ook nog die 24 Articles of Faith, ${ }^{5}$ terwyl hulle die Westminster Confession as 'n suiwere getuienis van die Woord van God aanvaar. Die Methodist Church of South Africa aanvaar as hulle "standards of doctrine" die „Fourty-four Sermons of John Wesley" en sy

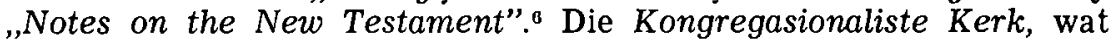
prinsipieel-dogmaties baie na aan die Presbiteriaanse Kerk staan, en waarvan verreweg die meeste lidmate Afrikaanssprekend is (want Kleurlinge), besit die Savoy Declaration of Faith and Order (van $1658^{7}$ as ,affirmation of faith" (i.p.v. „confession"), wat eintlik 'n herskrywing is van die Westminster Confession. Hulle wil egter niékonfessioneel wees. 
(2) Die ekumeniese verbintenisse van die Engelse kerkegroepe is veelvuldig en kompleks. Vir eers is die meeste ingeskakel by die Wêreldraad van Kerke, ${ }^{8}$ en wat Afrika betref by die All African Conference of Churches, ${ }^{9}$ en ten opsigte van S.A. by die South African Council of Churches. Die doel van lg. is o.m. ,to foster that unity which is both God's Will and His gift to the Church, by discussion, conferences, ecumenical studies, joint endeavour and in such other ways as may from time to time seem expedient"; voorts "to do all such things and to encourage all such things as may best be calculated to reduce in scope the differences, whether doctrinal or otherwise, presently existing among the Christian Churches"; verder is dit die begeerte van die Raad ,to see in South Africa a social order consistent with the gospel of Jesus Christ".10 Wat S.A. betref, bestaan daar náás die S.A.C.C. ook nog 'n Church Unity Commission waarby alle Engelse kerkegroepe, behalwe die Baptiste, ingeskakel is. Die doelstelling hiervan lees soos volg: „The Anglican, Congregational, Methodist and Presbyterian Churches believe that God calls His people to express visibly the unity given in Christ. Obedience to this call demands that we seek union with one another". ${ }^{11}$ Hierbenewens is daar kerkegroepe (bv. die Presbiteriaanse) wat ook by die World Alliance of Reformed Churches ingeskakel is - soos tewens ook die N.G.K. of N.H.K.

(3) Daar is ruim verskil in kerkregering, wat wissel van die presbiteriaanse stelsel (Presbyterian Church), biskoplike (Anglican Church) tot die independentistiese (Congregational en Baptist Church).

(4) Daar is verskil in liturgie.

(5) Uiteindelik speel die politieke situasie en oortuigings in S.A. nog steeds ' $n$ rol in kerklike verhoudinge. ${ }^{12}$

Dit kan ook nie betwyfel word nie dat die Engelse kerkegroepe tans meer belangstelling het vir die politieke en sosiale vraagstukke as vir teologiese, of miskien moet ons sê: belangstelling vir die relevansie van die teologie vír die politieke en sosiale probleme. ${ }^{13}$

Indien ons ons egter laat lei deur die optrede van Calvyn, wat selfs met die Anglikaanse Kerk noue kontak probeer opbou het, dan spreek dit vanself dat ons ook ten opsigte van ons Engelse broeders ' $n$ roeping het, $\mathrm{nl}$. om te begin met samesprekings en waar moontlik (bv. in groot stedelike sentra met sensusopnames) met samewerking. ${ }^{14}$

\section{Prognose}

Ons volstaan hier met enkele stellinge, waarvan sommige ook konklusies uit die voorafgaande is.

3.1. Ten opsigte van die vraag na eenheid van die divergerende kerkegroepe is daar drie houdinge. Eerstens 'n houding van indifferentisme, wat twee vorme aanneem: enersyds is daar diegene wat die vraag na die sigbare eenheid van die KERK as 'n volkome periferiese aangeleentheid beskou - 'n standpunt wat m.i. veral voorkom onder teoloë in die N.H.K. van Afrika - , en andersyds is daar diegene 
wat so weinig verwag van die huidige eenheidsgesprek dat hulle veel meer entoesiasme ontwikkel vir 'n eksterne ekklesiologie, 'n sg. „vrye kerk" buite die ,geïnstitusionaliseerde kerk". ${ }^{1}$ Tweedens is daar die houding van eksklusivisme waarvan die standpunt is dat die "eie" kerkegroep die ,alleenware kerk" is en dat álle ander kerkegroepe daarby moet aansluit. Hierdie standpunt, wat deur die Sinode van die G.K.S.A. in 1958 grondig afgewys is, en ook deur Totius bevraagteken is, ${ }^{2}$ kom tans nog voor by die Geref. Kerk (Vrygemaak) in Nederland. Derdens is daar die houding van toenadering waar op grond van die Skrif erns gemaak word met die sigbare eenheid van die KERK.

3.2. In die lig van die Nieu-Testamentiese ekklesiologie moet die verskeurde kerklike situasie van tans as sonde gesien en bely word, waaruit logies voortvloei dat alle Skrifverantwoorde pogings aangewend moet word om die sigbare eenheid van die KERK te herstel. Dit geld sowel die verhouding van die 3 Afrikaanse, asook dié van die Afrikaanse en Engelse kerkegroepe. ${ }^{3}$

3.3. Omdat die Bybel nie ' $n$ verskeurde KERK ken nie, is daar ook geen konkrete, direkte en ondubbelsinnige Skrifgegewens om die weg na die een KERK weer terug te vind nie. Tog sal 'n aantal Bybelse motiewe hier 'n groot rol speel, nl. waarheid, waaragtigheid en liefde, maar ook berou, skuldbelydenis, ${ }^{4}$ vergifnis en versoening.

3.4. Daar is drie moontlikhede om die verlore eenheid te herwin. Eerstens die moontlikheid van absorpsie, waar die groter kerkegroep die kleinere(s) opneem - wat veral die oogmerk is van die R.K.K. ${ }^{5}$; tweedens die moontlikheid van radikalisme, waar die kleiner kerkegroep van die grotere(s) verwag om by hóm in te skakel; en derdens die weg van bekering - vir almal -, en wel nie na mekáár toe nie, maar na die Here Jesus Christus, om langs dié weg van ootmoedige navolging van Christus ook mekáár te vind. ${ }^{3}$

3.5. Ons onderskei graag tussen drieërlei eenheid. Eerstens is daar die dialogiese eenheid, die eenheid-in-gesprek, wat ten opsigte van álle kerkegroepe geld - soos bv. die Engelse -, maar wat veral betrekking het op die R.K.K. Ons erken tewens die doop van die R.K.K. en ons besit saam dieselfde Apostolicum. Juis dít maak 'n gesprek met Rome nie alleen moontlik nie maar ook noodsaaklik. Die vraag is of die tyd nie ryp is dat daar in S.A. 'n Gespreksraad van Christelike Kerkegroepe in die lewe geroep moet word om hierdie interkerklike gesprek te voer nie. Hierdie samesprekings moet egter nie net op sinodale vlak nie maar ook in die plaaslike kerke gevoer word. ${ }^{7}$ Tweedens is daar die koöperatiewe eenheid waar daar veral op grond van ooreenstemming in die (meer uitgebreider) Belydenisskrifte sprake kan wees van samewerking op verskillende vlakke. Hier kom veral die N.G.K. en N.H.K. in die gesigsveld. Derdens noem ons die korporatiewe eenheid, d.w.s. die wérklike eenheid, een kerkverband. Hierop moet bg. twee altyd gerig wees. Voordat hierdie finale fase van eenheid egter bereik sal kan word, sal daar veel gesamentlike en openhartige gesprekke nodig wees; gesamentlike Bybelstudiekringe kan gereël word; jeugverenigings kan saam besin; realistieser samewerking in sending en evangelisasie kan onderneem 
word; sinodale deputate kan gesamentlik oor aktuele probleme besin om, waar moontlik, eensluidende of eenstemmige rapporte aan die onderskeie sinodes voor te lê. Die eintlike probleem is hier egter geleë by die vraag na kansel- en tafelgemeenskap, iets wat vroeër of later sonder twyfel ter sprake móét kom indien die eenheid van die KERK ons erns is. Slegs daar waar, onder toesig van die plaaslike kerkraad, die nagmaal vir álmal oop is, dáár is waarlik sprake van één kerk/KERK.'

3.6. Die doel van die samespreking en samewerking moet eerstens gerig wees op die eenheid van die KERK. Dit is nodig dat ons ons lig laat skyn en ons getuienis laat hoor, maar solank as wat die éénheid van die kerkegroepe ons nie ter harte gaan nie, sal al die gesprekke en saamwerk hoe langer hoe meer frustrerend word. Die doel moet tweedens wees: die eenheid van die KERK - en nie van die volk nie. Hierdie motief, wat nogal dikwels gehoor word, is 'n onsuiwere motief." Selfs KERK-eenheid mag nie as uiteindelike doel gesien word nie, want - en dit ten derde - die finale doel van die één KERK behoort altyd te wees die onbelemmerde ontplooiing van die Koninkryk van God (Joh. $17: 21$ ).

3.7. Die kritiese kriterium vir 'n gesprek oor KERK-eenheid kan niks anders wees nie as die Woord van God.

Ds. J. H. van Wyk.

(Gelewer voor G.T.V. Jaarvergadering, Ontdekkers, Junie 1972)

\section{VERWYSINGE}

1 My formulering. Die tema van die G.T.V.-Hoofbestuur lui soos volg: „Kerklike Korrespondensie en Gesprek. Problematiek t.o.v. verhoudinge en gesprek met die Afrikaanse en Engelse Kerke in Suid-Afrika". Die bcgrippe ,ekumene" (= wêreldwyd) en ,eenheid" (in teenstelling tot verskeurdheid) nie identies is nie en ek gebruik hulle onderskeidend, vgl. Acta Geref. Kerk in S.A. 1958, 66-67 en 1964, 156-157. Vgl. J. C. Hoekendijk: De Kerk binneste buiten, Amsterdam, 1964, 49, 191

\section{VERWYSING BY 1.1.}

1 Johannes Calvyn: Institutie of Onderwijzing in de Christelijke Godsdienst (vert.), Naamloze Vennootschap W. D. Meinema, Delft, z.j.

2 W. Nijenhuis: Calvinus Oecumenicus. Calvijn en de eenheid der kerk in het licht van zijn briefwisseling, 's-Gravenhage, Martinus Nijhoff, 1959. Vgl. P. J. Richel: Het Kerkbegrip van Calvijn, 1942; W. G. de Vries: Calvijns Oecumenische Betekenis, Goes, 1959 en W. Nijenhuis: Enkele aktuele vragen betreffende de oecumene, Wageningen, 1962.

3 Institusie IV, 1, 7.

4 Idem IV, 1, 2.

5 IV, 1, 5. Dubbele hakies (en telkens weer) van my.

6 IV, 1, 9

7 IV, 1,9 (so IV, 1, 11). Opvallend is (i) dat Calvyn nie die kerklike tug as kenmerk van die ware kerk beskou nie (wat nie beteken dat dit vir hom nie baie belangrik was nie!, - dit is die "senuwee van die kerk", IV, 
12,2 ), en (ii) dat hy nie maar net die prediking van die Woord van God noem nie maar ook die suiwere aanhoor daarvan. Ook G. P. Hartvelt wys hierop: Tastbaar evangelie (De sacramenten), De Graafschap, Aalten, z.j., 182. In IV, 1,10 noem hy slégs die aanhoor van die Woord! In IV, 2, 4 noem hy slegs die Wórd as nota ecclesiae.

8 IV, 1, 10.

9 IV, $1,10$.

10 IV, 1, 12.

11 IV, 1, 12. Calvyn noem hier slegs drié kernwaarhede; die „en dergelijke" definieer hy nie verder nie. Nijenhuis wys daarop dat dit opvallend is dat Calvyn nie die predestinasie hier noem nie, Calvinus, a.w., 282.

12 IV, 1, 12.

13 IV, 1, 13.

14 IV, 1, 14.

15 IV, 1, 14. Vgl. ook IV, 1, 19/27.

16 IV, 1, 15.

17 IV, 1, 17.

18 IV, $1,18$.

19 IV, 1, 3/7/8/9.

20 IV, 2, 1.

21 IV, 2, 2. Vgl. IV, 2, 5.

22 IV, 2, 4/7.

23 IV, 2, 7.

24 IV, 2, 9.

25 IV, 2, 9.

26 IV, 2, 9.

27 IV, 2, 10.

28 IV, 2, 12. Ook in 'n preek kom 'n soortgelyke skerp uitspraak voor: „want zij hebben niet eenig kenmerk van een Kerk", in Het Gepredikte Woord. Preeken van Johannes Calvijn (vert.), Deel V, T. Wever, Franeker, 2e druk (oorspr. 1552).

29 IV, 2, 12.

30 Calvinus: a.w., 278. Van dieselfde mening is ook D. Nauta: Calvijns afkeer van een Schisma in Ex Auditu Verbi. Theologische Opstellen aangeboden aan prof. dr. G. C. Berkouwer, J. H. Kok N.V., Kampen, 1965, 131-156 en D. W. Kolfhaus: Vom Christlichen Leben nach Johannes Calvin, Neukirchen Kreis Moers, 1949, 352. Daarom is die volgende opmerking van T. $\mathbf{N}$. Hanekom hoogs disputabel: „Organisatoriese kerkhereniging of vereniging van kerke op institutere vlak val buite sy ((Calvyn se)) program", asook dat Calvyn kies vir ,één Kerk, gegrond op één beleydenis, maar nêrens bepleit hy eên kerkverband nie", Kerk en Kerkbegrip by Calvyn in Ned. Geref. Teologiese Tydskrif, deel V, no. 3, Junie 1964, 151.

31 Calvinus: a.w., 219.

32 Calvinus: a.w., 179, 223.

33 J. J. F. Durand: Calvyn as Ekumeniese Gees in bg. N.G.T.T., 180. Eweneens oordeel A. D. R. Polman: Onze Nederlandsche Geloofsbelijdenis III, T. Wever, Franeker, z.j.: „Zo valt voor Calvijn de ware kerk niet samen met de Gereformeerde kerk. De Engelse, episcopaalse kerk, de Lutherse, zelfs de gemeenten der Waldenzen en Bohemers worden als ware kerken erkend" (234) en (i.v.m. art. 29 N.G.B.); "Onder de ware kerk wordt elke 
kerk verstaan, die aan de gestelde kenmerken voldoet. Daaronder worden alle kerken der Reformatie begrepen, al is er verschil in zuiverheid zowel in de leer als in de liturgie" (362). Ook Kolfhaus meen dat dit duidelik is ,dass für Calvin die Kirche nicht zusammenfallt mit einem einzelnen und einzigen Institut", a.w., 361. Dieselfde geld van Guido de Brez, opsteller van die N.G.B., vgl. Het Dogma der Kerk, Jan Haan N.V., Groningen, $1949,512$.

34 Calvinus: a.w., 204 (vgl. 298--299).

35 Idem, 205 (vgl. 303-305).

36 Idem, 210. R. Boon is nog meer uitgesproke: Apostolisch ambt en reformatie. Primair probleem der oecumene, G. F. Callenbach N.V., Nijkerk, 1965: „Dit staat echter als een paal boven water: uit het voorafgaande moet ons duidelijk zijn geworden, dat in tegenstelling tot de gangbare mening Calvijn allesbehalve de vader van de presbyteriale kerkstructuur is geweest. Zijn ambtsopvatting is veeleer diametraal tegenovergesteld aan een presbyteriale structuur, daar zij een uitgesproken episcopaal karakter draagt" (201-202).

37 Calvinus: a.w., 209.

38 Idem, 303.

39 Idem, 206.

40 Idem, 213. Ook Nauta wys daarop dat Calvyn t.o.v. die liturgie groot ruimte gelaat het, a.a. 132, 140, en Durand verwys na die advies van die Geneefse predikante aan die Geref. vlugtelinggemeente in die Lutherse stad Wesel om aan te pas ,in al die seremonies wat geen beslissende invloed op die belydenis van ons geloof het nie, sodat die eenheid van die kerk nie deur ons te groot gestrengheid of vreesagtigheid versteur word nie", a.a. 180 (m.v.n. C.R. XV, 80).

41 Calvinus: a.w., 213.

42 Idem, 213.

43 Idem, 214 (vgl. 303-305).

44 Idem 220. Vgl. Nauta: Calvyn wil geen skisma nie, behalwe waar 'n kerk ten volle van die diens aan God en die verkondiging van die Woord afgeval het, a.a. 154 .

45 Anders by Hanekom, a.a. 156, 158.

46 Calvinus: a.w., 301-303.

47 Durand ontken dit, a.a. 171.

48 Eweneens is dit teologies onhoudbaar om die „Koninkryk van God" met die "hemel" te identifiseer, soos T. Hamersma doen: De Katechismus in 52 Predikaties, Bloemfontein, 1919, 314-315.

\section{VERWYSINGE BY 1.2 .}

1 Koers, v. 16, no. 4, 1948/49, 111-125.

2 Agenda G.K.S.A. 1967, 349-358.

3 Veral Koers 1948/49, 111-125; Agenda 1967, 349-358 en Die Kosbare Goud, Kaapstad, 1942, 211-219. Frappant is dat hierdie siening ook gedeel word deur die Rooms-Katolieke teoloog Hans Küng: De Kerk (vert.), Paul Brand, Hilversum-Antwerpen, 1967, 93-102.

4 Kosbare Goud, a.w., 215 (vgl, egter 218).

5 Agenda 1967, a.w., 355. 
6 Jaarblad. Die Hammanskraalse Teologiese Skool, 1965, 15.

7 Agenda 1967, a.w., 351.

8 Koers, jg. 33, no. 3, Des. 1965, 244; Agenda 1967, a.w., 354 v.; Die Kerkblad, 28.10.1959, 9; Die Kerkblad, 11.4.1962, 7.

9 Die Kerkblad, 25.8.1954, 3. Vgl. Die Kerkblad, 28.10.1959, 9 en Acta 1964, 197.

10 Acta 1946, 30 (vgl. 53-54).

11 Acta 1949, 55. Onbewus van hierdie rapport het ek tot presies dieselfde konklusie gekom, Die Kerkblad, 17.7.1970, 9. Hierdie vraagstuk het vanaf die staanspoor groot probleme veroorsaak en dit kan bevraagteken word of dit selfs vandag na wense opgelos is, vgl. bv. Acta 1942, 89-90; Acta 1949, 33; (veral) Acta 1952, 92; Acta 1955, 157-166 (enger en ruimer korrespondensie), 240-241, 307-309; Acta 1964, 188-195, 199, 201; B. Spoelstra in Handleiding by die Kerkorde van die Gereformeerde Kerk in Suid-Afrika, Pro Rege-Pers, Potchefstroom, 1966, 321; S. P. van der Walt in Bulletin S.A.V.B.C.W., April 1969, 50. Die Nasionale Sinode het besluit dat die "besluite” van die G.E.S. eers geratifiseer moet word, Acta 1949, 322. Volgens Snyman is die huidige G.E.S. egter "tweeslagtig", Die Kerkblad, 11.4.1962, 6. G. C. Berkouwer is buitengewoon skerp in sy formulering dat die eenheid van Kerk oor nasionale grense heen sigbare gestalte moet aanneem, De Kerk 1. Eenheid en Katholiciteit, J. H. Kok, Kampen N.V., 1970, 153; vgl. onk H. du Plessis: Kerkverband tot oor die Nasionale Grense, Koers, jg. 33, no. 1, Aug. 1965, 28-45.

Koers, Des. 1965, 245. Eweneens Agenda 1967, 356.

13 Koers 1948/49, 125.

14 Jaarblad Hammanskraal 1965, a.a. 17. "Kerk" het hier die betekenis van 'n aantal (bv. N.G.) gemeentes. Dit toon ons hoe moeilik dit is om die Bybelse terminologie konsekwent te handhaaf.

Agenda 1967, 355.

Idem, 354.

Jaarblad Hammanskraal 1965, a.a. 16.

Kosbare Goud, a.w., 219.

Jaarblad Hammanskraal 1965, 16; Die Kerkblad, 7.9.1951, 2.

Openbaringsgeskiedenis van die Nuwe Testament (diktaat), Potchefstroom, 1967, 72. (Vgl. Acta 1958, 78-80, waar sy formulering deurskemer).

Agenda 1967, 356, en veral Die Kerkblad, 15.6.1960, 1-3, 5. Ook Die Kerkblad, 28.10.1959, 9; 11.4.1962, 7 .

Agenda 1967, 356; Die Kerkblad, 28.10.1959, 9; Acta 1964, 156.

Agenda 1967, 358. Vgl. Die Kerkblad, 18.8.1954, 3.

Koers 1965, 245.

Agenda 1967, 356.

Idem, 356.

Agenda 1967, 356. So in Agenda/Reports RES 1968, Amsterdam, 171. Vgl. ook J. D. du Toit hieroor: Versamelde Werke van J. D. du Toit VIII, Dagbreek-Boekhandel, Johannesburg, 1962, 16. Vir Snyman se kritiek op die Wêreldraad, vgl. Die Kerkblad, 18.8.1954, 2-3.

28 T. van der Walt, Agenda 1967, 363.

\section{VERWYSINGE BY 1.3.}

1 In die Skriflig, no. 2, Febr. 1967, 21. Die invloed van Nijenhuis is op- 
vallend sterk.

2 Skriflig, a.a., 21. So in sy Die Religieuse Grondmotief van die konsepsies van Visser 't Hooft met betrekking tot die Wêreldraad van Kerke. ' $n$ Wysgerige benadering, Boekhandel De Jong, Braamfontein, 1971, 280.

3 Skriflig, a.w., 21.

4 I.B.C. Studiestuk no. 6 (s.j.), 5. Vgl. Die Religieuse Grondmotief, a.w., 141 v. en sy opstel in Die Koninkryk van God, Potchefstroom, 1969, 295.

5 Agenda 1967, 378 (passim).

6 Die Koninkryk van God, a.w., 292.

7 Skriflig, a.a., 21. So in Die Koninkryk van God, a.w., 299 (287) en Die Religieuse Grondmotief, a.w., 281.

8 Skriflig, a.a., 21.

9 Idem, 21.

10 Agenda 1967, 378.

11 I.B.C. studiestuk, a.a., 4.

12 Skriflig, a.a., 21. Vgl. Die Koninkryk van God, a.w., 298.

13 Skriflig, a.a., 21. So in Die Koninkryk van God, a.w., 301.

14 Die Religieuse Grondmotief, a.w., 271 (vgl. 262-263).

15 Idem, 282. Eweneens in Die Kerkblad, jg. 74, no. 2104, 16 Junie 1971, 6.

16 I.B.C. studiestuk, a.a., 6.

17 Idem, 6. Vgl. Agenda 1967, 379 en Skriflig, a.a., 18, 19. Indien 'n gesprek met die R.K.K. gevoer behoort te word, is die huiwering onbegryplik waarom dit nie ook nie met die W.R.K. gedoen behoort te word nie, vgl. sy rapport, Acta 1964, 174-184 (,indien", 184).

18 Die Kerkblad, a.a., 6. Hy het tewens op die Sinode van 1961 'n sodanige beskrywingspunt van die Klassis Krugersdorpp toegelig, Acta 1961, 378.

19 Die Koninkryk van God, a.w., 285.

20 Idem, 294 (vgl. 299); ook Die Religieuse Grondmotief, a.w., 277-278. Vandaar ook Duvenage se kritiek van horisontalisme, immanentisme ens. teen Visser 't Hooft, a.w., 265 v.

21 I.B.C. studiestuk, a.a., 6; Agenda 1967, 379; Skriflig, a.a., 18, 19.

22 Die Kerkblad, a.a., 6.

23 Skriflig, a.a., 21.

24 Die Kerkblad, a.a., 6.

25 Die Religieuse Grondmotief, a.w., 283.

26 Die Koninkryk van God, a.w., 298 (290). Sien Die Religieuse Grondmotief, a.w., 282-283.

27 Die Religieuse Grondmotief, a.w., 78.

28 Vgl. idem, $264 \mathrm{v}$.

29 By Rik Valkenburg: Discussie-interviews over VERONTRUSTING, J. H. Kok N.V., Kampen, 1971, 31. Ook Bonhoeffer was van oortuiging dat die dogmatiese verskille binne die Protestantisme groter was as die tussen Rome en Reformasie, vgl. G. Th. Rothuizen: Aristocratisch Christendom. Over Dietrich Bonhoeffer, J. H. Kok N.V., Kampen, 1969, 176.

30 In VERONTRUSTING, a.w., 34.

31 Die Koninkryk van God, a.w., 295-296. Vgl. Die Religieuse Grondmotief, a.w., 277-278. 


\section{VERWYSINGE BY 2.1.1.}

1 O.a. by A Moorrees: Die Nederduitse Gereformeerde Kerk in Suid-Afrika, 1652-1873, Kaapstad, 1937, 846.

2 Vgl. J. P. Jooste: Die Geskiedenis van die Gereformeerde Kerk in SuidAfrika 1859-1959, Potchefstroom (1959), 67-74; G. C. P. van der Vyver: Professor Dirk Postma 1818-1890, Pro Rege-Pers, Potchefstroom, 1958, 331-338; B. Spoelstra: Die „Doppers” in Suid-Afrika 1760-1899, Nasionale Boekhandel, Johannesburg, 1963, 194 v.

3 Acta 1869, p. 37.

4 Acta 1910, p. 109-113.

5 Acta 1913, pp. 49, 109.

6 Acta 1916, 57, 106.

7 Acta 1924, 61 v., 191.

8 Acta 1927, 60, 186.

9 Vgl. Acta 1946, 28 en Jooste: Die Geskiedenis, a.w., 353, 365. Op die Sinode van 1918 het 'n beskrywingspunt van Reddersburg gedien i.v.m. 'n Geref. internasionale Sinode; vir hierdie doel moes die Sinode eers in oorleg tree met die Hollandse Kerke in S.A., Acta 1918, 124. Die Sinode benoem hiervoor studiedeputate. Dr. H. H. Kuyper het die saak ook in 1924 te Rustenburg aangeroer, Acta 1942, 87-88. Vir 'n mooi samevatting van die ontstaan van die G.E.S., vgl. Acta 1942, 87-89, en Jooste: Die Geskiedenis, a.w., 353 v.

10 Baie name is oorweeg vir die G.E.S., bv. „Interkerklike Sinode", "Internasionale Sinode" (Acta 1933, 20); "Gereformeerde Wêreldsinode" (Acta 1945, 17); „Ekumeniese Konsilie” (Acta 1945, 178); „Internasionale Sinode van Geref. Kerke" (Acta 1946, 54).

11 Acta 1933, 20. Vgl. Acta 1942, 93, 96.

12 Acta 1933, 40, 47.

13 Acta 1936, 36.

14 Idem, 37. Die eerste deputate van die G.K. was ds. I. D. Kruger en dr. E. L. J. Venter (idem, 177).

15 Acta 1939, 156. Dit is 'n leemte in die boek van Jooste, a.w., dat hy die periode 1939-1959 nie behandel nie.

16 Acta 1939, vgl. pp. 153-154, 155-159,160, 217-218. Die finale besluit is op 217-218.

17 Idem, 157.

18 Idem, 158.

19 Idem, 218.

20 Idem, 158-159.

21 Acta 1942, 92.

22 Idem, 92.

23 Idem, 93.

24 Idem, 95 (no. 2), 97 (no. 8). Hiermee is die besluit van 1869 dus nietig verklaar. Die gebruik van die woord "susterkerk" is later herroep, Acta 1964, 108-109 (vgl. Acta 1958, 403).

25 Acta 1942, 96.

26 Acta $1945,79,80$.

27 Idcm, 80. Die deputate was di. I. D. Kruger, J. H. Boneschans en dr. E. L. J. Venter. 
28 Idem, 81 (pt. 6).

29 Idem, 80.

30 Idem, 81.

31 Acta 1949, 59-60.

32 Idem 322. (Blykbaar het die kontak met die N.H.K. om een of ander onverklaarbare rede doodgeloop).

33 Idem, 323.

34 Idem, 178-180. Vgl. 284-285. Die Sinode het „met goedkeuring kennis geneem" van die reëlings i.v.m. hierdie gesamentlike dankdienste, 284.

35 Idem, 178. Ook op die Sinode van 1952 word gerapporteer dat ons in S.A. ten opsigte van die drie Afrikaanse kerkegroepe van "Susterkerke" spreek, Acta 1952, 236.

36 Acta 1952, 62. Die N.H.K. sal ook uitgenooi word.

37 Idem, 238-239.

38 Idem, 188.

39 Idem, 189.

40 Idem, 189.

41 Idem, 189.

42 Idem, 191.

43 Idem, 197.

44 Idem, 212.

45 Idem, 217.

46 Acta 1955, 306. Die kommissie was dus van oordeel dat die ander twee Afrikaanse kerkegroepe ,,behoudend" is!

47 Idem, 309.

48 Idem, 157-166.

49 Idem, 168/170.

50 Idem, 168/170.

51 Idem 170.

52 Idem, 170, 271.

53 Idem, 170, 271. Op p. 168 is ook - vir die mandaat - verwys na Acta $1942,125$.

54 Acta 1955, 268-269/271.

55 Idem, 318.

56 Idem, 319.

57 Idem, 320.

58 Acta 1958, 69. Vgl. Agenda 1958, 217. Die eerste sodanige versoek was van ds. Paul Nel van die N.G.K. (1910) en die tweede van ds. L. E. Brandt van die N.H.K. (1936).

59 Acta 1958, 78.

60 Idem, 78-80.

61 Idem, 79.

62 Idem, 80. Vgl. Acta 1967, 415.

63 Acta 1958, 51.

64 Acta 1961, 160.

65 Idem, 378.

66 Vgl. die besluit, Acta 1961, 378-388.

67 Acta 1964, 154-199.

68 Idem, 201-203.

69 Idem, 197-199. 
70 Opvallend is dat die woord sonde hier i.v.m. kerklike geskeidenheid gebruik word: „Geskeidenheid van kerke is 'n sondige verskynsel”; „met sonde kan daar nie vrede wees nie", Acta 1964, 197. (Vgl. Acta 1967, $390,415)$.

71 Acta 1964, 198.

72 Idem, 202.

73 Idem, 203

74 Idem, 530. Die motivering is sonder konkretisering. Die besluit beteken egter nie dat die Teologiese Skool van die G.K.S.A. die maandblad Pro Veritate nie sal ontvang nie, Acta 1967, 322.

75 Acta 1964, 63; my kursivering. Maar daarmee is aan die woorde ,ander kerk" 'n veel enger konnotasie gegee as aan die woorde "ander kerk" in art. 9 K.O. Dit is verder 'n oop vraag of die Sinode nie hier sy grense oorskry het nie, aangesien die nagmaal die sakrament van die plaaslike kerk is (W. J. Snyman) waar die plaaslike kerkraad toesig hou

76 Acta 1967, 357-411.

77 Idem, 411-429.

78 Idem, 361-362. Vgl. T. van der Walt: „die Nuwe Testament ken nie so iets as 'n ,onsigbare kerk' nie", idem, 389.

79 Idem, 365 (367).

80 Idem, 366. Daar word gewys op die feit dat hierdie dispute oorwegend tussen teoloë plaasgevind het en „nie tussen amptelike afgevaardigdes van kerke nie", 367.

81 Idem, 365.

82 Idem, 359-368.

83 Idem, 369. Die besluit dat predikante uit ander kerkegroepe hulle eers tot die Teologiese Skool op Potchefstroom moet "wend" vir 'n sertifikaat van die kandidaatseksamen alvorens hulle in G.K.S.A. kan dien, is m.i. 'n verenging van die 1955-besluit oor enger korrespondensie, 52 (so Acta $1970,128)$ - indien dit ook sou geld vir predikante en proponente uit kerkegroepe waarmee ons in enger korrespondensie staan.

84 Acta 1967, 412-426.

85 Idem, 426.

86 Idem, 415.

87 Idem, 429.

88 Idem, 428. Die sinodale deputate het van die kerkraad ,nadere informasie" gevra, maar het niks verneem nie, 428-429. (Vermoedelik het die korrespondensie tussen die deputate en die kerkraad nie hul bestemming bereik nie, J.H. v. W.).

89 Acta 1970, 57-59. Blykbaar is ook nou afstand gedoen van die naam Tussenkerklike Kommissie soos goedgekeur in 1961. (Die rapport oor Ekumeniese Sake (85-96) bevat niks nuuts nie).

90 Idem, 58 (en 59).

91 Idem, 58. Waaroor sou die brief van Christian Council of South Africa, waarvan net „kennis geneem" is, gehandel het? 434 .

92 Idem, 59.

93 Idem, 59.

94 Idem, 60, 89. In 1967 is gestel dat dit slegs „voorlopige riglyne" sal wees (a.w., 369).

95 Idem, 60. Hierdie is die dérde benaming! 
96 Idem, 69.

97 Idem, 69. So in Acts RES 1968, 55.

98 Idem, 69-70. Let op die „verskillende soorte kontak". So reeds Acts RES 1963, 53. Ons Sinode wil ook nie die korrespondensie met die G.K. Nederland oorhaastig verbreek nie, 80 . A Troost is egter van oordeel dat die situasie in die G.K. Nederland dusdanig versleg het dat die moontlikheid van "noodgemeentes" - binne dieselfde kerkverband! - oorweeg moet word, Fundamenten en Perspectieven van Gereformeerd Zijn, Bodegraven, 1971, 26.

99 Idem, 463-464.

$100 \mathrm{Vgl}$. Jooste: Die Geskiedenis, a.w., 373-377.

101 Acta 1958, 182, 193.

102 Acta 1961, 170. (Vgl. ook Acta 1970, 364 v.).

103 Acta 1967, 427.

104 Die Hervormer, Aug. 1968, 24. A. J. van Staden weer meen dat die N.H.K. by die G.E.S. „aansluiting moet soek", Herv. Teologiese Studies, jg. 24, afl. 1, s.j., 65.

105 RES Agenda/Reports 1968, 215.

106 Ons verwys in hierdie verband na die eenheidsgesprekblad, EEN, die eerste uitgawe (1971) waarvan versorg deur die teologiese studente van die N.G.K. Kweekskool te Stellenbosch. Vgl. ook J.A.K. in Loog, April 1972, 10: „Die gedagte dat die verskillende Afrikaanse kerke mekaar slegs op hoë vlak kan ontmoet en dat dáár só iets van kerklike eenheid verwag kan word, hou nie rekening met die groter wordende bchoefte onder veral jongeres in die kerke om mekaar van hart tot hart te ontmoet nie".

\section{VERWYSINGE BY 2.1.2.}

1 Vgl. Acta 1967, 415 (pt. 6).

2 B. Spoelstra in Handleiding by die Kerkorde, a.w., 20. So by H. Bouwman: Gereformeerd Kerkrecht II, J. H. Kok N.V., Kampen, 1970 (2), 145-146: „De organische eenheid der kerk treedt juist in de gemeenschappelijke belijdenis aan den dag".

3 C. Augustijn behandel die Belydenisskrifte m.i. té relativerend, Kerk en Belijdenis, J. H. Kok N.V., Kampen, 1969.

4 Vgl. G. C. Berkouwer oor die „sentrum”: „En het is duidelijk, dat de kerk in alle bezinning over de belijdenis altijd weer op deze centraliteit en radicaliteit wordt teruggeworpen. We komen hier m.i. in aanraking met het meest centrale punt van alle belijdenis-problematiek...", Verontrusting en Verantwoordelijkheid, J. H. Kok N.V., Kampen, 1969, 144. Ons benodig m.i. 'n dringende studie oor hierdie tema van "hart" en „periferie", want wat presies is die "hart" van die Evangelie? Vgl. bv. die volgende: „De triniteit... is de kern van het Christelijk geloof" (H. Bavinck: Gereformeerde Dogmatiek II, J. H. Kok N.V., Kampen, 1928 (4), 300; en insgelyks in Het Dogma der Kerk, a.w., 157); Die Christologie is "het hart der dogmatiek" (H. Bavinck, G.D. III, a.w., 1929, 254); Die uitverkiesingsleer is "die hart van ons gereformeerde belydenis" (G. C. P. van der Vyver: Ken en Vertrou, Johannesburg, 1968, 157); In die versoeningsleer ,gaan dit om die hart van die Evangelie" (F. W. Buytendach: Die Kerkblad, 3 Mei 1972, 8). Hoeveel "harte" het die geloof of belydenis of Evangelie? 
$5 \mathrm{Vgl}$. H. Volten se pleidooi vir reduksie, Rondom het Belijden der Kerk, J. H. Kok N.V., Kampen, 1962, 209: „Wie de drie formulieren als grondslag voor de kerk aanneemt en blijft aanvaarden, kan niet anders dan de kerkelijke verdeeldheid sanctioneren tot Christus' wederkomst toe..."

6 Vgl. Herman Ridderbos in Geref. Weekblad, 16.4.1971, 282: „Men kan, als onderget., de grootste waardering en eerbied hebben voor de historische belijdenisgeschriften en toch van mening zijn, dat zij in hun taal, opzet, wijze van denken en uitdrukking in vele opzichten niet meer geschikt zijn als belijdenis voor onze tijd". B. Wentsel pleit ook vir 'n nuwe Belydenisskrif in die plek van die bestaande, en noem 5 redes daarvoor, Geref. Weekblad, 15.10.1971, 86-87. Vgl. ook P. J. Coetzee, Die Kerkblad, 8 Maart 1972, 7 en R.E.S. News Exchange, 23 Febr. 1971, 669-670.

7 Hans Küng: De Kerk, a.w., 295.

8 By Kolfhaus: Vom christlichen Leben, a.w., 156.

9 Koers (Opinieblad), jg. 2, no. 31, 5 Junie 1971, 22.

10 Discussie-interviews over VERONTRUSTING, a.w., 29.

11 Dit was selfs oorweeg om die vraag na „nuwe belydenisskrifte” op die agenda van die G.E.S. te plaas, vgl. Acta G.K.S.A. 1942, 89 (sien ook Acta 1952, 71).

12 'n Kernvraag wat Ridderbos aan Berkouwer stel i.v.m. die eenheid van die KERK, is of Berkouwer nie „hetgeen hij als pluriformiteit van kerken eerst heeft uitgeworpen, toch als pluraliteit of pluralisme-binnen-de-enekerk weer binnen (haalt), zich daarbij nauw aansluitende bij de R.K. pluralisme-theologie (Van Rahner e.a.)". En dan vervolg Ridderbos: „Beslissend is de vraag... wat in de kerk wél en wat niet als legitieme interpretatie van de bijbelse boodschap aanvaard mag worden", Geref. Weekblad, 30 Okt. 1970, 98.

\section{VERWYSINGE BY 2.2 .}

1 Ons handel veral oor die Engelse kerkegroepe in Suid-Afrika. Die Geref. Kerk in S.A. staan in enger korrespondensie met verskeie Engelse kerkegroepe oorsee: Christian Reformed Church U.S.A., Reformed Church of New Zealand, Reformed Church of Australia, Free Church of Scotland, sien Almanak van die Geref. Kerk in S.A., 1972, 131. 'n Mooi skets van die verskillende Engelse kerkegroepe in S.A. is te vind in die Acta G.K.S.A. 1949, 59-60. K. Runia het ook 'n insiggewende artikel oor die situasie in Australië geskryf, Geref. Weekblad, 25 Maart 1966, 277.

2 Vermelding verdien die feit dat op die Sinode van 1876 (van die G.K.) 'n uitnodiging ontvang is om verteenwoordig te wees op die Algemene Konsilie van Presbiteriaanse Kerke te Edinburgh, Skotland. Die Sinode het met genoeë daarvan kennis geneem, maar het geen afvaardiging gestuur nie, Acta 1876, 15/76.

3 Acta 1949, 60.

4 Idem, 59.

5 Manual of Law Practise and Procedure of the Presbyterian Church of S.A., 1971, 93-99. Ons moet daarop wys dat ook die G.K.S.A. die 39 Articles en Westminster Confession in ekumeniese verband aanvaar, Acta 1955, 243 (pt. I) en 252 (g. II).

6 Acta 1949, 60. 
7 Savoy Declaration of Faith and Order, Albert Peel, Independent Press, 1939.

8 Die Anglikaanse en Rooms-Katolieke Kerke voer ook onderling diskussie, vgl. B. C. Pawley: Anglican-Roman Relations, Kent, 1964.

9 Ook die G.K.S.A. stuur waarnemers hierheen, Acta 1970, 91.

10 Constitution of the South African Council of Churches (pamfletvorm).

11 Proceedings of the 69 General Assembly, Presbyterian Church in S.A. 1970, 160. (Die Baptiste is nie hierby ingeskakel nie).

12 So bv. lewer die Engelse kerkegroepe tans skerp kritiek op die „onregverdige" politieke situasie in S.A. wat dan deur die Afrikaanse kerkegroepe ondersteun word, terwyl hulle nog nooit standpunt ingeneem het ten opsigte van die „eeu van onreg van die Afrikaners nie", Woord en Daad, April 1972, 5.

13 Vgl. hier D. J. Bosch: Possibilities and Limitations of Ecumenical Actions in South Africa in Das Gespräch 10/71 (van die Christelike - Lutherse Akademie), 20-24, waarin hy veel meer verwag van samewerking as van samespreking (24).

14 Ook Kuyper had veel kontak met die Engelse Kerk, en Puchinger is selfs van oordeel "dat Kuyper in zijn jonge jaren erg onder die indruk is geweest van de Engelse Kerk", Gesprek over de onbekende Kuyper, J. H. Kok N.V., Kampen, 1971, 48.

\section{VERWYSINGE BY 3. PROGNOSE}

1 Vgl. H. M. Kuitert: Anders Gezegd, J. H. Kok N.V., Kampen 1970, 178, 182 en Geref. Weekblad, 13 Maart 1970, 243. Dit is moontlik dat namate die institutêre, offisiële, kerklike weg tot eenheid vrugteloos blyk te wees, die ongeduldiges al hoe meer hierdie weg sal volg - die sg. pad van „churchianity" na „Christianity".

2 Versamelde Werke van J. D. du Toit VII, Dagbreek, Johannesburg, 1961, 509. Selfs 'n behoudende teoloog soos M. P. van Dijk skryf dat "we moeten bereid zijn onze identiteit „als Gereformeerde Kerken)) prijs te geven", solank ons maar kerk van Christus is, Geref. Weekblad, 21 Jan. 1972, 188. Vgl. ook die uitspraak van J. H. Velema in Kerk en Pers '68, Bosch en Keuning N.V., Baarn, 1969, 7-8.

3 In ' $n$ sekere sin is sowel die Afrikaanse as Engelse kerkegroepe volkskerke, omdat hoofsaaklik beperk tot 'n bepaalde volk in S.A. Dit sou 'n besonder boeiende kerkhistoriese studie wees om na te gaan in watter mate die Afrikaanse en Engelse kerkegroepe polities-ideologiese invloede ondergaan het.

4 Vgl. Küng: De Kerk, a.w., 318: „Een eenwording van de gescheiden christelijke kerken is onmogelijk zonder de critische historische reflexie, die de ogen niet sluit voor de schuld van de eigen kerk aan de splitsing"; en: „En daarom zal de eerste stap tot opheffing van de splitsing altijd de belijdenis van schuld en de bede om vergeving zijn: tegenover God, de Heer van de kerk, en tegelijk tegenover de broeders", 327.

5 Küng wys egter daarop dat die kerkbegrip van die R.K.K. nie (meer) absolutisties is nie, De Kerk, a.w., 326, 329. Vgl. Geref. Weekblad, 8 Maart 1968, 255.

6 Baie mooi verwoord by Küng, De Kerk, a.w., 338: „Zo is noch de ,terugkeer' van de ene kerk naar de andere, noch de ,uittocht' uit de ene naar 


\section{In die Skriflig}

de andere de weg naar de eenheid, doch de gemeenschappelijke ,ommekeer', conversie van alle kerken naar Christus en zo naar elkaar". Vgl. veral die hele stuk vanaf 318 tot 341 .

7 „De eenwording van de kerken kan helemaal niet van boven af gedecreteerd worden, maar moet van onder af, vanuit de gemeenten en de individuen, innerlijk groeien", Küng, De Kerk, a.w., 331.

8 "Slechts waar men samen kan bidden, samen het woord Gods kan horen en het geloof kan belijden, samen maaltijd kan houden, daar is éen kerk. Slechts daar belijdt met uiteindelik niet vele Heren, maar én Heer, niet vele Geesten, maar één Geest, niet vele Goden, maar éen God!, Küng, a.w., 325 .

9 Vgl. bv. 'n stelling soos die volgende - al handel dit nie spesifiek oor KERK-eenheid nie -: „Want die Afrikaanse Kerk is Kerk van Jesus Christus ter wille van die Afrikanervolk in die eerste plek", A. D. Pont: Die Afrikaner, 15 Jan. 1971, 18. Vgl. ook A. P. Treurnicht in Triomf (Jaarboek SABRA), no. 2, 1966, 49. 